\title{
Micro-Nano Scale Surface Coating for Nucleate Boiling Heat Transfer: A Critical Review
}

\author{
Shoukat A. Khan ${ }^{1}$, Muataz A. Atieh ${ }^{2}$ and Muammer $\operatorname{Koç}^{1, * \mathbb{C}}$ \\ 1 Sustainable Development Division (SDD), College of Science and Engineering (CSE), Hamad bin Khalifa \\ University (HBKU), Qatar Foundation (QF), Education City, Doha P.O. Box 5825, Qatar; \\ shokhan@hbku.edu.qa \\ 2 Qatar Environment and Energy Research Institute (QEERI), Hamad bin Khalifa University (HBKU), Qatar \\ Foundation (QF), Education City, Doha P.O. Box 5825, Qatar; mhussien@qf.org.qa \\ * Correspondence: mkoc@qf.org.qa
}

Received: 2 October 2018; Accepted: 11 November 2018; Published: 16 November 2018

check for updates

\begin{abstract}
Nucleate boiling is a phase change heat transfer process with a wide range of applications i.e., steam power plants, thermal desalination, heat pipes, domestic heating and cooling, refrigeration and air-conditioning, electronic cooling, cooling of turbo-machinery, waste heat recovery and much more. Due to its quite broad range of applications, any improvement in this area leads to significant economic, environmental and energy efficiency outcomes. This paper presents a comprehensive review and critical analysis on the recent developments in the area of micro-nano scale coating technologies, materials, and their applications for modification of surface geometry and chemistry, which play an important role in the enhancement of nucleate boiling heat transfer. In many industrial applications boiling is a surface phenomenon, which depends upon its variables such as surface area, thermal conductivity, wettability, porosity, and roughness. Compared to subtractive methods, the surface coating is more versatile in material selection, simple, quick, robust in implementation and is quite functional to apply to already installed systems. The present status of these techniques for boiling heat transfer enhancement, along with their future challenges, enhancement potentials, limitations, and their possible industrial implementation are also discussed in this paper.
\end{abstract}

Keywords: nucleate boiling; phase change heat transfer; energy efficiency; surface coating; pool and flow boiling; heat exchangers

\section{Introduction}

Heat transfer is a thermophysical phenomenon and is involved in every energy conversion, utilization, and recovery process. Its enhancements require physical improvements in the heat transfer system, which will, in turn, decrease its size (material saving), pumping power and volume needs [1]. Any developments in this area would potentially lead to improvements in the overall energy efficiency and reduction in size and cost of the system and operations. The main advantage of the phase change heat transfer is its ability to transfer a large amount of heat energy within a given time and volume. Boiling is a multi-phase and efficient thermal energy transfer process due to its high latent heat [2]. Boiling heat transfer is applied in processes where high heat flux is needed to be removed i.e., nuclear power plant [3,4], desalination [5,6], or where space is confined such as electronic cooling and thermal management of data centers [7-10], thermal management of batteries [11], heat pipes [12,13] and microfluidic systems [14-17].

Available heat transfer enhancement techniques in literature can be broadly classified as active, passive and compound technique, as shown in Table 1 . In the active techniques, the overall heat transfer of the system is improved by the help of external power while in passive techniques, no external 
power is required. Compound techniques, on the other hand, are the combination of both active and passive techniques at the same time. Passive techniques have higher reliability, as compared to active techniques, due to the absence of moving components and auxiliary power [18]. Treated surfaces methods mainly deal with coating or alteration of the surface structure at fine, i.e., micro to nano, scale. Recent developments in the field of micro-nano scale manufacturing and surface functionalization expanded further the boundaries of heat transfer enhancement through surface treatment. Although micro-nano scale surface modifications are mainly used in the phase-change heat transfer process i.e., boiling, condensation, and freezing [19-22], they are also found effective for single-phase heat transfer convection [23-25].

Table 1. Classification of Heat transfer enhancement techniques [1].

\begin{tabular}{cc}
\hline Passive Techniques & Active Techniques \\
\hline Treated Surfaces & Mechanical Aids \\
Rough Surfaces & Surface Vibration \\
Extended Surfaces & Fluid Vibration \\
Displaced Enhancement Devices & Electrostatic Fields \\
Swirl Flow Devices & Injection \\
Coiled Tubes & Suction \\
Surface Tension Devices & Jet Impingement \\
Additives for Liquids & \\
Additives for Gases & Compound Enhancement \\
\hline \multicolumn{2}{c}{ together. } \\
\hline
\end{tabular}

Working fluid and solid surfaces are two main variables to modify for enhancing boiling heat transfer [26-28]. Most of the time, the working fluid is not possible to modify due to restrictions that arise from applications i.e., water desalination, steam power generation cycles etc. Hence, the surface remains as a key variable to modify. This is where micro-nano scale surface enhancements through surface roughening (usually through fabrication and deformation) or surface coating techniques come into play. In almost all of the industrial applications, boiling is a surface phenomenon and depends on properties of the surface such as roughness, porosity, and wettability. In nucleate boiling heat transfer, nucleation, growth, frequency, and departure of vapor bubbles are strongly linked to topology and chemistry of the associated surface. The micro-nano scale coating provides an efficient solution for altering the surface parameters, according to the optimization conditions of the specific application [29]. Compared to subtractive methods, surface coating is simple, quick, more versatile in material selection and geometry, robust in implementation and quite functional to apply to already installed systems.

The aim of this paper is to review surface coating methods applied to nucleate boiling heat transfer, specifically with recently developed micro-nano scale coating techniques. A critical review of the present status of these methods, along with their future challenges, enhancement potentials, limitations and their possible industrial implementation are discussed in this paper.

\section{Enhancement of Nucleate Boiling Heat Transfer: Overview}

Heat is transferred from a solid surface to liquid during nucleate boiling, and convection is the main heat transfer mechanism due to the motion of the fluid [30]. Surface tension and difference in density, which results in buoyancy force, are two important parameters other than latent heat in this phenomenon. The buoyancy driven flow and latent heat of boiling heat transfer results in its high heat transfer rate, as compared to single-phase convection [31]. In boiling heat transfer, nucleate boiling is a desirable phenomenon due to its high thermal performance. Due to the involved phase-change heat transfer, the physics of this phenomenon is very complex and still not very well understood [32]. We will discuss these briefly in the coming sections. 
It is important to understand the mechanism of how boiling phenomena transfer a huge amount of heat energy. During nucleate boiling, a bubble grows at nucleation site on the hot surface and moves up by overcoming the surface tension. Heat is being removed when the bubble departs from the hot surface. The rate of overall heat transfer is significantly affected by dynamic parameters of the bubble such as bubble nucleation density, departing diameter, frequency, growth rate and waiting period [33]. According to the vapor-liquid model, the amount of heat transfer with the bubble is equal to the heat energy required to raise the temperature of an equal amount of liquid from liquid temperature to the average of liquid and wall temperature [34]. Approximately 100 times more energy, in form of latent heat, required to boil $1 \mathrm{~g}$ of water than the energy required to raise its temperature by $5 \mathrm{~K}$ [35].

In order to understand the physical mechanism of how bubble transfers energy during nucleate boiling, other models such as the transient conduction model (TCM), the micro-layer heat model (MLM), and the contact line model (CLM) have been developed, as reported in the literature. According to TCM of Mikic et al. [36], when vapor is departing from the surface it takes away a superheated layer from its surrounding, equivalent to twice its diameter, and then cold water comes in contact with this surface and the process repeats. According to MLM of Sydney and Edwards [37], a thin liquid layer at the hot surface is trapped by a growing bubble, which evaporates and transfers a large amount of heat. The resultant decrease in temperature after evaporation of microlayer was also validated later by Moore and Mesler [38] and Hendricks and Sharp [39]. While CLM of Stephan and Hammer [40] states that the main cause of heat transfer in nucleate boiling is the evaporation of thin meniscus of the liquid layer at the contact point of three phases (solid substrate, gas bubble, and liquid). After studying of all three models, Kim [41] concluded that micro-convection and transient conduction are the main phenomenon in the heat transfer of a bubble during boiling. There are different opinions among researchers about these models. But all agree on the point that the resultant boiling bubble in nucleate boiling appears at the solid surface, which reflects the importance of surface modification as a key variable to enhance the overall phenomena.

Before going into detail about the boiling heat transfer enhancement through micro-nano scale surface coatings, the physics involved in the boiling phase-change heat transfer is reviewed here. Nukiyama [42] introduced the boiling curve, which describes different states of the nucleate pool boiling mechanism, as shown in Figure 1. The transition from Nucleate Boiling Heat Transfer (NBHT) to Film Boiling (FB), Critical Heat Flux (CHF), and Heat Transfer Coefficient (HTC or $h$ ) are the key factors to understand for efficiency improvement of this phenomenon. In addition, CHF and HTC are also the key parameters for the performance measurement of the boiling process. Increasing HTC and CHF have a substantial effect on the overall efficiency, cost, and safety of the process [43].

\subsection{The Transition from Nucleate Boiling Heat Transfer (NBHT) to Film Boiling (FB)}

The phenomena of NBHT can be best understood by the well-known boiling curve, Figure 1. In this curve, $q_{s}^{\prime \prime}$ represents the heat flux, $T_{s}$ is the surface temperature, $T_{\text {sat }}$ is the saturation temperature and $h$ is the heat transfer coefficient. The nucleation of bubbles on hot surface, and hence the boiling process, starts when $T_{s}$ exceeds $T_{\text {sat }}$. Nucleate boiling heat transfer (NBHT) is a boiling regime where more mature vapor bubbles nucleate on the surface and are quickly removed. New bubbles appear at nucleation sites just after the departure of these bubbles and the process continues. This motion of bubbles produces more advanced fluid mixing in the region near the surface and enhances $q_{s}^{\prime \prime}$ and $h$ [31]. The number of nucleation sites increase and bubbles merge until its maximum limit called critical heat flux $q_{\max }^{\prime \prime}$.

By increasing heat flux above a certain limit, the rate of bubbles generation overcomes its rate of departure. The bubbles start to merge together and form a film of vapors. As the thermal conductivity of vapor is less than that of the liquid, $q_{s}^{\prime \prime}$ starts to decrease after this point and a layer of bubbles covers the whole surface forming a vapor film, which forces the transformation from NBHT to Film Boiling (FB) regime. Due to transition from convection to radiation, heat transfer from the surface decreases, which results in a significant increase in surface temperature. The transition from nucleate to film 
boiling is an undesirable state, however, there is always a limit for every boiling above which this conversion occurs. Improvement in NBHT and delaying FB are two common goals in enhancing the performance of boiling heat transfer devices. Nucleate boiling and film boiling, for the same surface and working fluid at different working conditions, are shown in Figure 2.

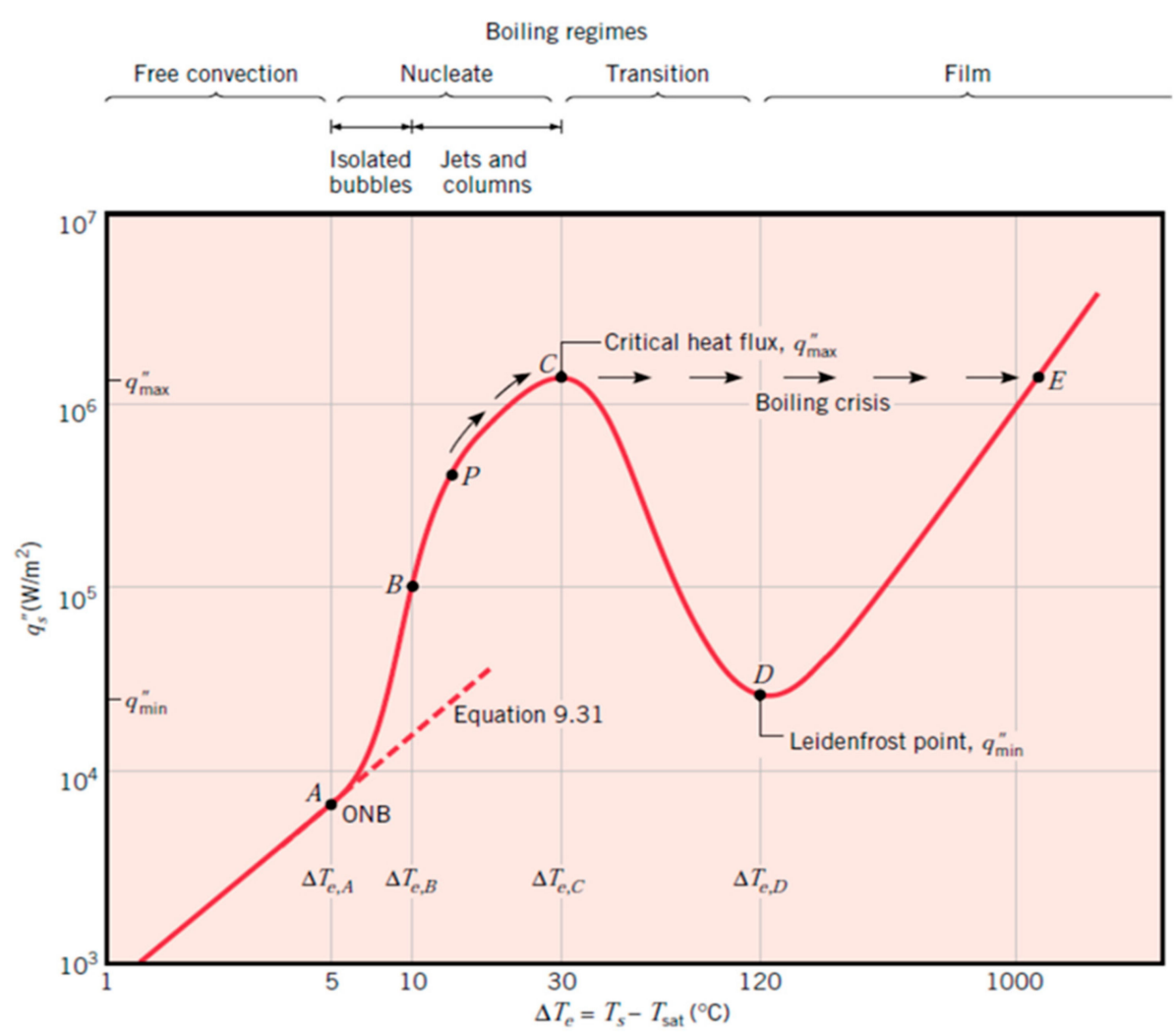

Figure 1. Boiling heat transfer curve, $q_{s}^{\prime \prime}$ heat flux as a function of (Ts - Tsat) [31].

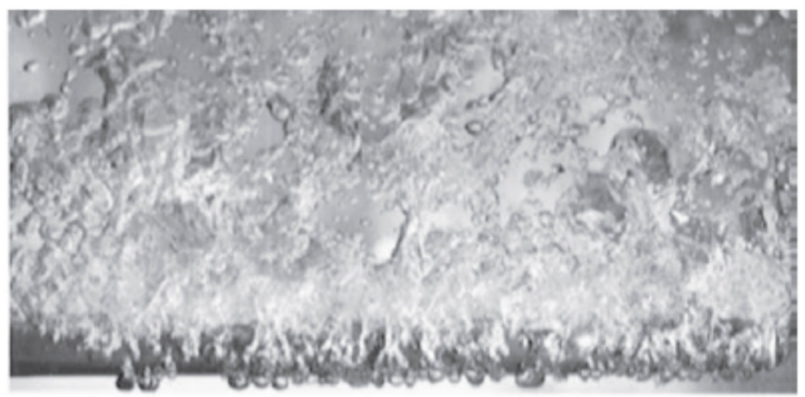

(a)

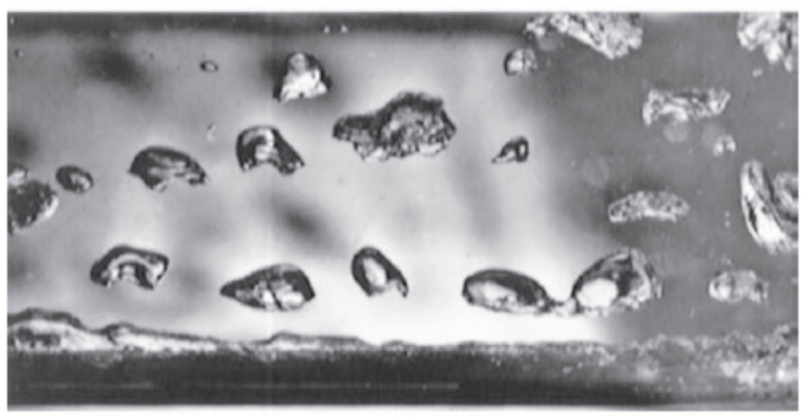

(b)

Figure 2. For same substrate and boiling fluid, two different conditions: (a) Nucleate boiling; (b) Film boiling [31]. 


\subsection{Critical Heat Flux (CHF)}

CHF was first introduced in the hydrodynamic model centered on the principle of Kelvin-Helmholtz instability $[44,45]$. CHF is the maximum limit of NBHT occurring when $q_{s}^{\prime \prime}=q_{\max }$ and is also performance parameter. Due to high efficiency of the boiling process near CHF, every design process' goal is to work near this limit. But care needs to be taken, as a little increase in surface temperature can lead the process to inefficient film boiling zone [31].

For the efficient and safe operation of boiling heat transfer system, it is very important to know the precise value of CHF $[46,47]$. High CHF value with low surface temperature is the goal of every design of NBHT. The very high value of CHF but at a very high surface temperature (i.e., low $h$ ) or vice versa are not suitable conditions for the nucleate boiling process. Although the phenomenon of CHF is not still well understood, however, there are studies in literature trying to predict CHF value and attempt to explain. The review of such studies is presented by Liang and Mudawar [48,49]. For example, Kandlikar [50] reported that vapor recoil force causes the bubbles to make a film on the substrate surface. This study also presented a theoretical model for $\mathrm{CHF}$ and verified with experimental data.

\subsection{Heat Transfer Coefficient (HTC/h)}

Thermodynamic efficiency of NBHT can be best reparented by HTC [35], which can be seen as the slope of the NBHT curve. If $q_{s}^{\prime \prime}$ increased beyond CHF, HTC decreased drastically due to formation of vapor film on hot surface. This increases the surface temperature undesirably and often reached up-to destructive level, known as "dry out" condition.

\section{Surface Coatings for Boiling Heat Transfer Enhancement}

Ho et al. [51] reported for the first time the effectiveness of surface roughness in NBHT process. Topography is a geometric property of a surface that varies with pitch, shape, height, depth, etc. and each one of them significantly affects the function of the surface. This indicates infinite possibilities for surface modification and provides ample room for improvement of boiling heat transfer [35,52]. Surface coatings provide a robust and efficient solution to modify surface according to the requirement of the heat transfer phenomena. Researchers have used different coating techniques for boiling heat transfer enhancement i.e., sintering [53], spraying [54], plasma coating [55] and electrochemical deposition [56]. They have used materials such as metals, polymers, ceramics and composites for complex geometries and shapes, i.e., 3D porous structures, pyramids, bumps, pillars in micro-nano-scales. This modification of micro-nano scale affects different parameters in boiling heat transfer such as nucleation sites, roughness, wettability, and porosity.

Comprehensively, surface (s), temperature $(\mathrm{T})$ and pressure $(\mathrm{P})$ conditions along with working fluid properties (i.e., viscosity, thermal conductivity and heat capacity) are main parameters for NBHT [27], expressed as:

$$
\mathrm{q}_{\mathrm{NB}}^{\prime \prime}=f(\text { fluid property, surface characteristics }) *\left[\mathrm{~T}_{\text {wall }}-\mathrm{T}_{\mathrm{sat}}(\mathrm{PI})\right]^{\text {constant }}
$$

In NBHT, important properties of working fluid are density, viscosity, surface tension, thermal conductivity; properties of the surface include geometry, wettability, and roughness, whereas process conditions include operating temperature and pressure $[57,58]$. Engineered surfaces at micro-nano scale for boiling heat transfer facilitate nucleation and maximize CHF by preventing or delaying film boiling [59-61]. For example, the cavities on the surface originate bubbles and entrap them inside [62-66]. Similar studies also substantiated that surface roughness and cavities increase the number of nucleation points during NBHT $[67,68]$.

Surface modification techniques for NBHT enhancement can be classified as (1) mechanical shaping processes i.e., machining, deforming using roughness tools, $\mathrm{CNC}$, laser machining and sandblasting techniques $[51,69,70]$, (2) surface coating processes i.e., chemical vapor deposition (CVD), physical vapor deposition (PVD), spraying, plasma, (3) chemical processes i.e., oxidation, 
etching and photochemical etching [71-74] and (4) micro-electro-mechanical systems (MEMS) and nano-electro-mechanical systems (NEMS) techniques [46-48]. In the literature, the performance of any modified coated surface is evaluated by comparing its heat transfer coefficient (HTC) and critical heat flux (CHF) with the corresponding untreated surface [75-77]. In the coming sections, we will discuss different types of surface coatings to enhance boiling heat transfer. The classification of the coating can be summarized as follows: (a) Nanoparticle coating (NPC): metals and ceramics; (b) Micro-scale surface coatings (MSSC); (c) Hydrophobic and hydrophilic surface coating to control wettability; and (d) Carbon-based nanoparticles coating (CbNPC). The hybrid coating as combination of above coatings are covered in this section.

\subsection{Nanoparticle Coatings: Metals and Ceramics}

Apparent properties of nanofluids such as high thermal conductivity, a non-linear relationship between the particles concentration and thermal conductivity, and high HTC make it an interesting medium for boiling heat transfer [78-83]. You et al. [84] investigated for the first time the effect of nanofluids for boiling heat transfer. They studied alumina-water nanofluids (concentration up to 0.01 vol.\%) vs. pure water for pool boiling heat transfer and stated an increase in CHF up to $200 \%$. Later on, the focus of research changed when Vassallo et al. [85] reported the deposition (settlement) of nanoparticles on the substrate, during the study of pool boiling for silica nanofluids and silica micro-solution. They explained that it was not the gravitational force, which caused their settlement, but rather, was the evaporation of fluid during bubble departure. During the growth of the bubble, the nanoparticles settled down and attached to the hot surface. The concentration of these particles increased with time and formed a porous layer. This observation has been confirmed recently by optically observing the active nucleation site, by Kim [86], Figure 3.

Kim et al. examined surface modification with nanofluids (alumina, zirconia, and silica nanoparticles) and its effect on overall heat transfer [87-90]. They found that there was no considerable difference between the samples treated with different nanofluids. The deposition (settlement) of nanoparticles on the heated surface caused porous coatings, which increased the overall surface area and wettability of the surface, and decreased its static contact angle as shown in Figure 4. Hence, an increase in wettability and overall surface area caused an appreciable increase in nucleate boiling CHF. Many other researchers have investigated the role of nanoparticle coatings on a substrate surface and reached the same conclusion [91-93]. Watanabe et al. [94] investigated the adhesion of the deposited nanoparticle coating and its detachment effect on NBHT performance. They reported that adhesion force of nanoparticle coating highly depends on the type, size and distribution of the nanoparticle material. Both CHF and HTC values were reported to increase with the nanoparticle coating.

For nanofluids in NBHT, researchers also reported both enhancement and decline of CHF and HTC [95-97]. The settlement of nanoparticles increased the surface roughness [98] and wettability [99], and hence boiling performance but on the other hand suspended nanoparticles in nanofluid might have hindered the movement of the bubbles and caused a decrease in the overall heat transfer performance $[100,101]$. In all these and similar investigations, the results were always compared by changing the surface from clean to nanoparticle-deposited surface and keeping the nanofluid same. To get a clear understanding of the contribution of nanofluids and of the suspended nanoparticles, White et al. [102] performed experiments by changing the base liquid from pure to nanofluid. They found that increased surface roughness due to nanoparticle deposition significantly increased the performance for base fluid and declined slightly for nanofluid. The increase is attributed to surface roughness and decline to the suppression of the bubble formation and motion of suspended nanoparticles. Nanofluid boiling is considered widely for the nanoparticle coating in pool boiling heat transfer. However, the deposition or settlement of nanoparticles using boiling technique is difficult to control. White et al. [103] used electrophoretic deposition (EPD) technique to coat stainless steel plate. 
EPD have a high level of automation and control where charged particles are attracted by a conducting substrate using an external electric field.

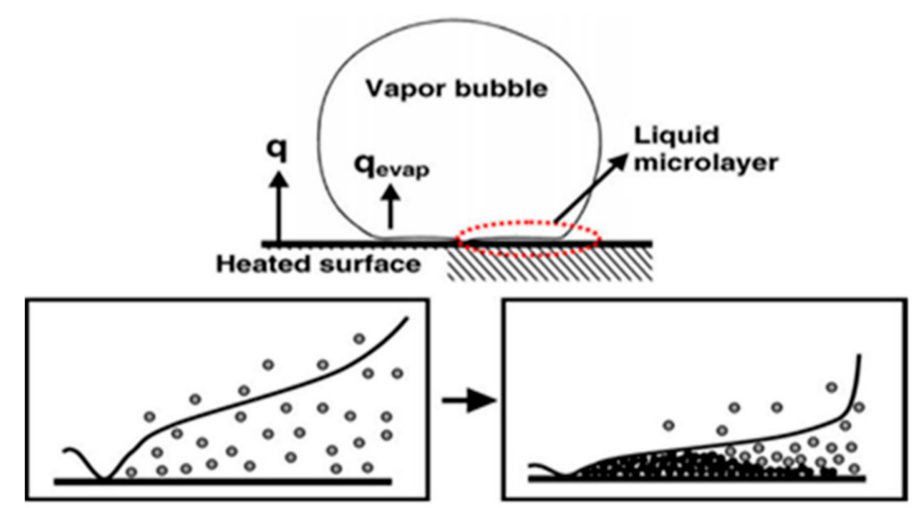

Figure 3. Nanoparticle coating during nucleate boiling heat transfer [86].

a

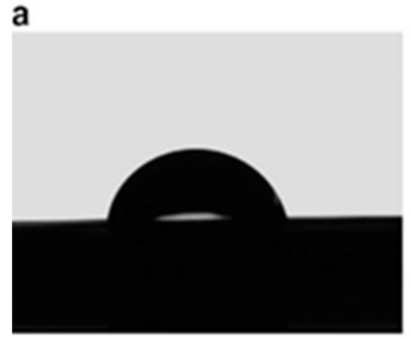

$\theta=79^{\circ}$

c

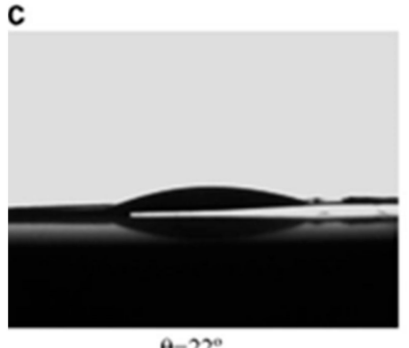

b

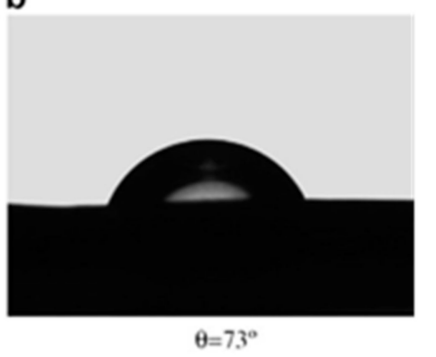

d

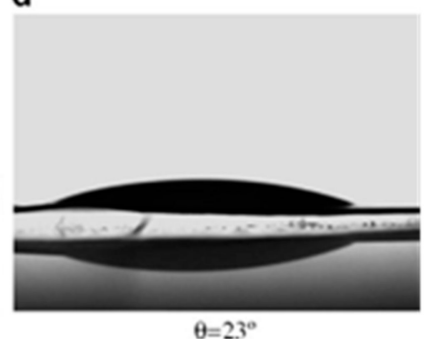

Figure 4. Wettability changes of stainless steel surface by the representation of contact angle: (a) Drop of pure water on stainless steel surface boiled in pure water; (b) Drop of alumina nanofluid on stainless steel surface boiled in pure water; (c) Drop of pure water on stainless steel surface boiled in alumina fluid; (d) Drop of alumina nanofluid on stainless steel surface boiled in alumina nanofluid [86].

Nanoparticles are also used with other micro-nano coatings as a hybrid coating due to its properties of act as nucleation points for bubble generation and also increase an overall surface area [104-106]. Using this concept, nanoparticles can be used to increase bubble nucleation. Jaikumar and kandlikar [107] investigated the effect of nanoparticle coating on selectively open microchannel for pool boiling heat transfer. Three different coating patterns, i.e., overall coating, the coating on fin tops and coating between the fins (channels) were analyzed as shown in Figure 5. The nanoparticle coated areas appeared as the source points for bubble nucleation and enhanced the heat transfer, i.e., both CHF and HTC. The greatest enhancement out of these three configurations was noted for the channel coatings. The uncoated fin top worked for the water supply as a jet impingement mechanism, for nucleation points inside the channels. Nanoparticle coating can also be applied for controlling surface wettability to enhance NBHT. Kim et al. [108] investigated hybrid $\mathrm{Al}_{2} \mathrm{O}_{3}$ and reduced graphene oxide (RGO) colloids, and compared their performance with that of RGO and $\mathrm{Al}_{2} \mathrm{O}_{3}$ nanofluid. The maximum increase in $\mathrm{CHF}$ for $\mathrm{RGO}$ and $\mathrm{Al}_{2} \mathrm{O}_{3}$ suspension were $37 \%$ and $54 \%$, 
respectively. However, $\mathrm{Al}_{2} \mathrm{O}_{3}$ and $\mathrm{RGO}$ composite resulted in the highest enhancement in $\mathrm{CHF}$ with $473 \%$. In a similar study, Gupta and Misra [109] reported 260\% and 68\% enhancement in HTC and $\mathrm{CHF}$ for hybrid $\mathrm{Cu}$ and $\mathrm{Al}_{2} \mathrm{O}_{3}$ colloids.

Forrest et al. [110] coated nickel wire and stainless-steel plate with silica nanoparticles using the method of the layer by layer assembly. This study reported a significant increase in CHF and HTC. Depending upon final treatment, both hydrophilic and hydrophobic surfaces were obtained and reported enhanced results for CHF and HTC. Also, calcination was applied to make the coating porous, which might affect $\mathrm{CHF}$ as the overall area was increased. The comparative analysis of $\mathrm{CHF}$ enhancement using metals and ceramics nanoparticles coating, among referenced articles, can be seen in Figure 6. Similar studies of surface coating with nanoparticles, NBHT, are summarized in Table 2.

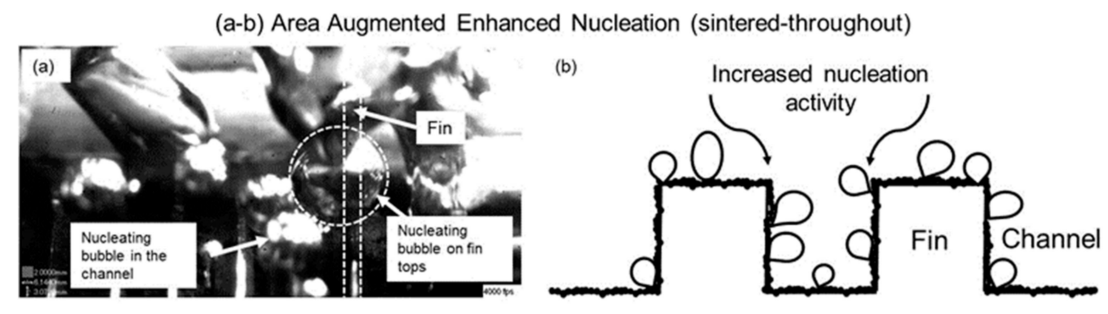

(c-d) Bubble Induced Liquid Jet Enhancement - Type - 1 (sintered-fin-tops)

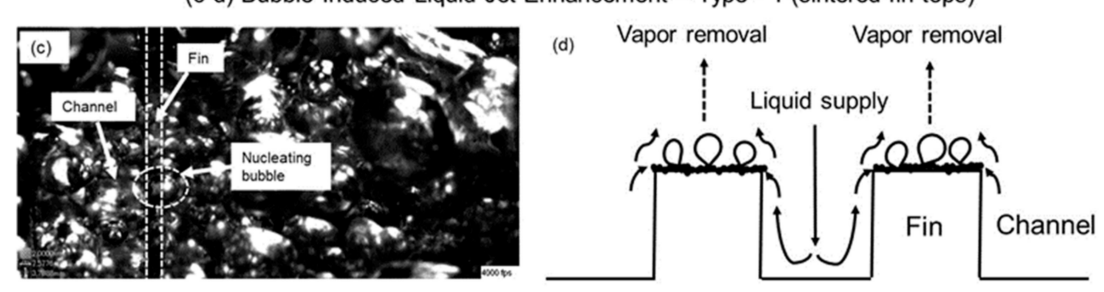

(e-f) Bubble Induced Liquid Jet Enhancement - Type - 2 (sintered-channels)

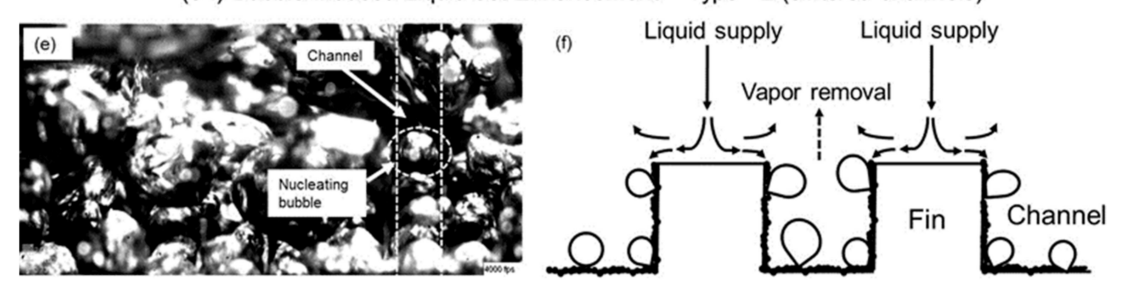

Figure 5. Proposed mechanism of selectively coated micro channel's heat transfer [107].

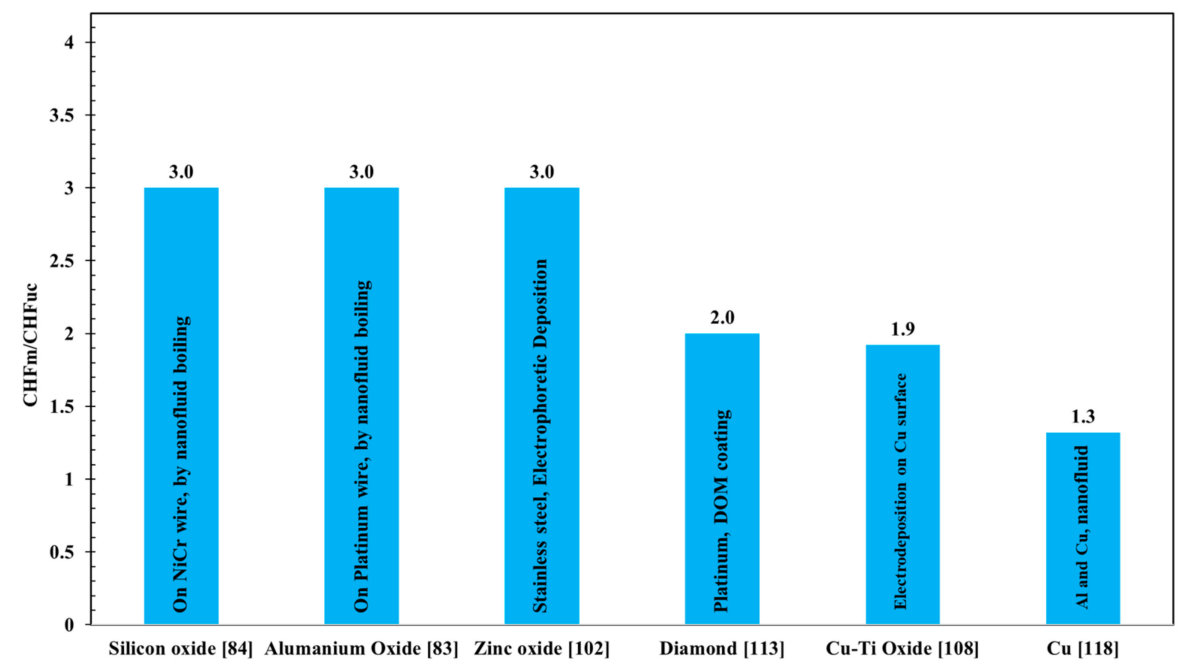

Figure 6. Maximum enhancement of Critical Heat Flux (CHF) by modification of the substrate with nanoparticles. Refer to Table 2, for detailed conditions of the studies listed on the $X$-axis. On $Y$-axis, " $\mathrm{m}$ " represents coated modified surface and " $u n$ " represents the uncoated untreated surface. 
Table 2. Nanoparticle coatings for boiling heat transfer.

\begin{tabular}{|c|c|c|c|c|c|c|}
\hline S. No & Substrate & $\begin{array}{c}\text { Type of } \\
\text { Nanoparticles }\end{array}$ & $\begin{array}{l}\text { Preperation } \\
\text { Techniques }\end{array}$ & Working Fluid & Enhancement & Ref. \\
\hline 1 & Nickel wires & Silica nanoparticles & $\begin{array}{l}\text { Layer by layer (lbl) } \\
\text { assembly method }\end{array}$ & Water & $100 \%$ & [110] \\
\hline 2 & Cu plate & $\mathrm{Al}_{2} \mathrm{O}_{3}$ & Nanofluid boiling & Water & Enhanced & [111] \\
\hline 3 & $\mathrm{Cu}$ & $\mathrm{TiO}_{2}$ & Nanofluid boiling & Distilled water & HTC by $38 \%$ & [112] \\
\hline 4 & $\mathrm{Cu}$ & $\begin{array}{c}\mathrm{Al}, \mathrm{Cu}, \mathrm{Ag} \text { and } \\
\text { diamond particles }\end{array}$ & $\begin{array}{c}\text { Dipping } \\
\text { and backing }\end{array}$ & FC-72 & $\begin{array}{l}\text { Enhancement: } \\
\text { up to } 4.5 \text { times } \\
\text { in HTC and } \\
2 \text { times in CHF }\end{array}$ & [113] \\
\hline 5 & Platinum & Diamond & DOM coating & FC-72 & $\begin{array}{c}\simeq 100 \% \text { CHF } \\
\text { enhancement }\end{array}$ & [114] \\
\hline 6 & Cu plate & $\mathrm{ZrO}_{2}$ & Nanofluid boiling & Water & Enhanced & [115] \\
\hline 7 & Stainless stell disk & $\mathrm{ZnO}$ & $\begin{array}{c}\text { Electrophoretic } \\
\text { deposition }\end{array}$ & ZnO-propylene & $200 \%$ & [103] \\
\hline 8 & $\begin{array}{l}\text { untreated } \\
\text { rectangular heater }\end{array}$ & $\mathrm{Al}_{2} \mathrm{O}_{3}$ & Nanofluid boiling & Water & $32 \%$ & [116] \\
\hline 9 & Nicr wire & $\mathrm{SiO}_{2}$ & Nanofluid boiling & Water & $\begin{array}{c}\text { Enhanced by } \\
3 \text { times }\end{array}$ & [85] \\
\hline 10 & $\begin{array}{l}\text { Aluminum } \\
\text { and copper }\end{array}$ & $\begin{array}{l}\mathrm{Cu}, \mathrm{Al} \text {, bronze, and } \\
\text { corundum particles }\end{array}$ & $\begin{array}{l}\text { Plasma sprayed } \\
\text { coating }\end{array}$ & Freon & $\begin{array}{c}\text { Max. } \\
\text { Enhancement } \\
\text { up-to } 32 \%\end{array}$ & [117] \\
\hline 12 & $\begin{array}{c}\text { Small horizontal } \\
\text { tube with diameter } \\
4 \text { to } 6.5 \mathrm{~mm}\end{array}$ & $\mathrm{Al}_{2} \mathrm{O}_{3}$ & Boiling nanofluid & Water & Enhanced & [65] \\
\hline 13 & $\begin{array}{c}\text { Pt Wire And } \\
\text { Heater(Square) }\end{array}$ & $\mathrm{Al}_{2} \mathrm{O}_{3}$ & Nanofluid Boiling & Water & CHF By $200 \%$ & {$[84]$} \\
\hline 14 & $\begin{array}{c}\text { Cu machined } \\
\text { surface and } \\
\text { polished surface }\end{array}$ & $\mathrm{Al}_{2} \mathrm{O}_{3}$ & Nanofluid Boiling & water & $\begin{array}{c}\text { Enhancement } \\
\text { up-to: } 7 \% \text { in } \\
\text { CHF, and } 37 \% \\
\text { in HTC }\end{array}$ & [118] \\
\hline 15 & Cu surface & $\mathrm{Cu}-\mathrm{Al}_{2} \mathrm{O}_{3}$ & $\begin{array}{c}\text { Electrochemical } \\
\text { deposition }\end{array}$ & DI water & $\begin{array}{l}\text { Enhancement } \\
\text { up-to: } 68 \% \text { in } \\
\text { CHF, and } 260 \% \\
\text { in HTC }\end{array}$ & [109] \\
\hline 16 & Cu surface & $\begin{array}{l}\text { GO and } \mathrm{Cu} \text { particles } \\
\text { coating }\end{array}$ & $\begin{array}{l}\text { Screen printing and } \\
\text { electrodeposition }\end{array}$ & water & $\begin{array}{c}\text { Enhancement } \\
\text { up-to: } 1.8 \text {-fold in } \\
\text { CHF, and } \\
\text { 2.4-fold in HTC }\end{array}$ & [119] \\
\hline 17 & $\mathrm{Cu}$ surface & $\begin{array}{l}\text { Micro-nanostructured } \\
\text { surfaces }\end{array}$ & $\begin{array}{l}\text { Femtosecond laser } \\
\text { processing }\end{array}$ & $\mathrm{N}$-pentane & $\begin{array}{c}\text { Enhancement } \\
\text { up-to: } 60 \% \text { in } \\
\text { CHF, and } \\
300 \% \text { in HTC }\end{array}$ & [120] \\
\hline 18 & Cu surface & $\begin{array}{c}\mathrm{TiO}_{2} \text { nanoparticles } \\
\text { film }\end{array}$ & $\begin{array}{c}\text { Electron beam } \\
\text { evaporation method }\end{array}$ & R134a & $\begin{array}{l}\text { HTC increased } \\
\text { by } 87.5 \%\end{array}$ & [121] \\
\hline 19 & Cu surface & $\begin{array}{l}\mathrm{SiO}_{2} \text { nanoparticles } \\
\text { film }\end{array}$ & $\begin{array}{l}\text { Electron beam } \\
\text { evaporation } \\
\text { technique }\end{array}$ & water & $\begin{array}{l}\text { HTC increased } \\
\text { by } 80 \%\end{array}$ & [122] \\
\hline 20 & Cu surface & $\begin{array}{c}\mathrm{Cu}-\mathrm{TiO}_{2} \\
\text { nanocomposite }\end{array}$ & Electrocodeposition & DI water & $\begin{array}{l}\text { CHF increased } \\
\text { up to } 92 \%\end{array}$ & [109] \\
\hline 21 & $\begin{array}{l}\text { Flat Stainless } \\
\text { steel surface }\end{array}$ & $\begin{array}{c}\mathrm{Al}_{2} \mathrm{O}_{3} \text { nanoporous } \\
\text { surface }\end{array}$ & $\begin{array}{l}\text { Electrophoretic } \\
\text { deposition }\end{array}$ & Pure SES36 fluid & $\begin{array}{c}\text { Maximum HTC } \\
\text { increased } \\
\text { by } 76.9 \%\end{array}$ & [123] \\
\hline
\end{tabular}

\subsection{Wettability: Hydrophobic and Hydrophilic Coatings}

Recent studies showed that hydrophilic and hydrophobic surfaces have significant abilities for boiling heat transfer enhancements [124-128]. Modified surfaces with the ability to enhance HTC (Heat Transfer Coefficient) and CHF (Critical of Heat Flux) values show at least one of the following properties: (a) increase in the frequency of the bubbles, (b) increase in the nucleation sites, (c) reduction of bubble's contact area, (d) low onset superheat for nucleate boiling [129,130]. 
Betz et al. [131] reported wettability behavior for boiling heat transfer, i.e., hydrophilic surfaces delay film formation while hydrophobic increase the number of nucleation density. They studied different patterns including hydrophilic and hydrophobic networks for pool boiling, as shown in Figure 7. For all the patterns, higher results of heat transfer coefficient (HTC) and critical heat flux (CHF) were reported. The maximum enhancement of $65 \%$ and $100 \%$ were achieved for HTC and CHF, respectively. In another study, Betz et al. [132] studied hydrophilic, hydrophobic, superhydrophilic, superhydrophobic, biphilic and superbiphilic coated surfaces as shown in Figure 8 Superhydrophilic (SPHi) are the surfaces with close to zero contact angle and superhydrophobic (SHPo) are surfaces with a contact angle of larger than $150^{\circ}$ with water. While biphilic are surfaces of hydrophilic and hydrophobic collocate and superbiphilic are surfaces with juxtaposing of SPHi and SHPo surfaces. Interestingly, enhanced results for CHF and HTC were achieved for biphilic surfaces as compared those of surfaces of uniform wettability. Very high values of CHF over $100 \mathrm{~W} / \mathrm{cm}^{2}$ and HTC over $100 \mathrm{~kW} / \mathrm{m}^{2} \mathrm{~K}$ were obtained for superbiphilic surfaces. They developed an analytical model to describe the enhanced behavior of these surfaces.
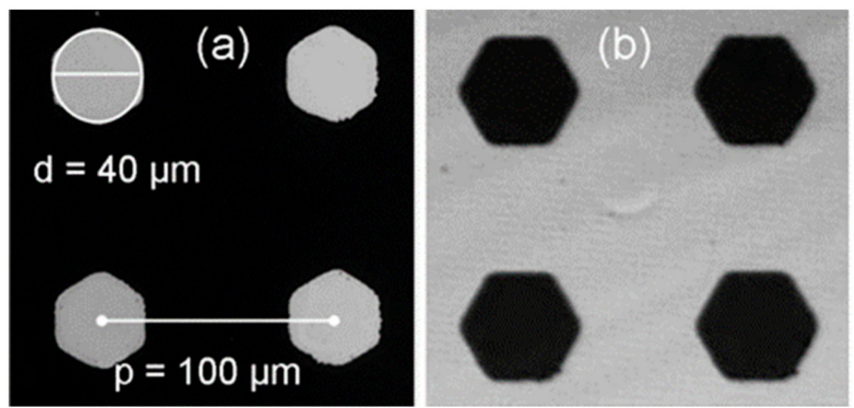

(c)

Figure 7. Patterns of hydrophobic and hydrophilic as gray and black colors coating [131].

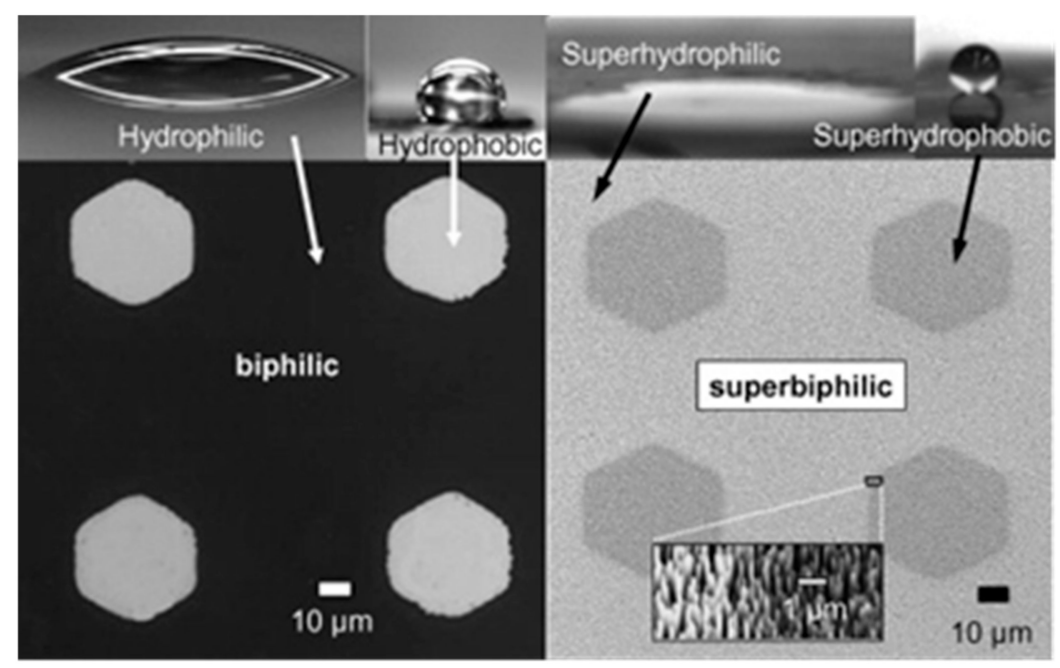

Figure 8. Four different types of hydrophilic, hydrophobic, super hydrophilic, super-hydrophobic, biphilic and superbiphilic surfaces [132].

Hsu and Chen [133] used a coating of nano-silica particles on $\mathrm{Cu}$ surface to change wettability from superhydrophilic to super-hydrophobic. Wettability of the surface was modified by changing its chemistry and topography. This study presented a simple model for the relation between bubble growth and wettability of the surface. Zupančič et al. [129] introduced a new method of using pulsed neodymium-doped yttrium aluminum garnet (Nd:YAG) laser for biphilic hydrophobic/superhydrophilic pattern coating from polydimethylsiloxane-silica. Biphilic surfaces were developed with different spots sizes on stainless-steel foil, Figure 9. Results showed that smaller hydrophobic dots increased the bubble's nucleation frequency and decreased its diameter. 
While surfaces with larger dots promoted NBHT and have high HTC at low heat flux. Highest CHF of $200 \%$ higher was achieved as compared with an untreated stainless-steel surface. An optimum-sized biphilic pattern was suggested in this study.

A network of hydrophobic on hydrophilic surfaces gives enhanced results for boiling heat transfer as reported by many researchers. However, hydrophobic and superhydrophobic coated surfaces do not show improved results as they promote the transition from nucleate to film boiling. In order to understand this phenomena, Takata et al. [134] prepared superhydrophobic surfaces by coating fine particles of nickel and PTFE. A static contact angle of $152^{\circ}$ was achieved. The results showed the formation of a vapor film on the heated surface even before the starting of nucleate boiling. At saturation temperature, bubbles appeared and combined with each other to form a film of vapor. However, it is worth noting that in some cases hydrophobic coating with very high conductivity gives enhanced performance. For example, carbon nanotubes (CNT) are highly hydrophobic and conductive in nature: studies proved that their coating gives significant enhancement results in boiling heat transfer [134].

Takata et al. [135] reported the superhydrophilic surface as an ideal heat transfer surface. $\mathrm{TiO}_{2}$ coating has high affinity to the liquid and its contact angle reaches to almost zero in ultraviolet light. Using this concept, they studied $\mathrm{TiO}_{2}$ coating on $\mathrm{Cu}$ and glass for pool boiling and reported 2 times enhancement in CHF. The durability of such modified surfaces in intense boiling conditions is still a major challenge. Further work needs to be performed with respect to durability, cost and a better understanding of boiling heat transfer behavior on biphilic surfaces [129]. For wettability alteration, various other coating material and techniques have been designed, developed and tested in literature and enhanced results are reported, as summarized in Table 3.

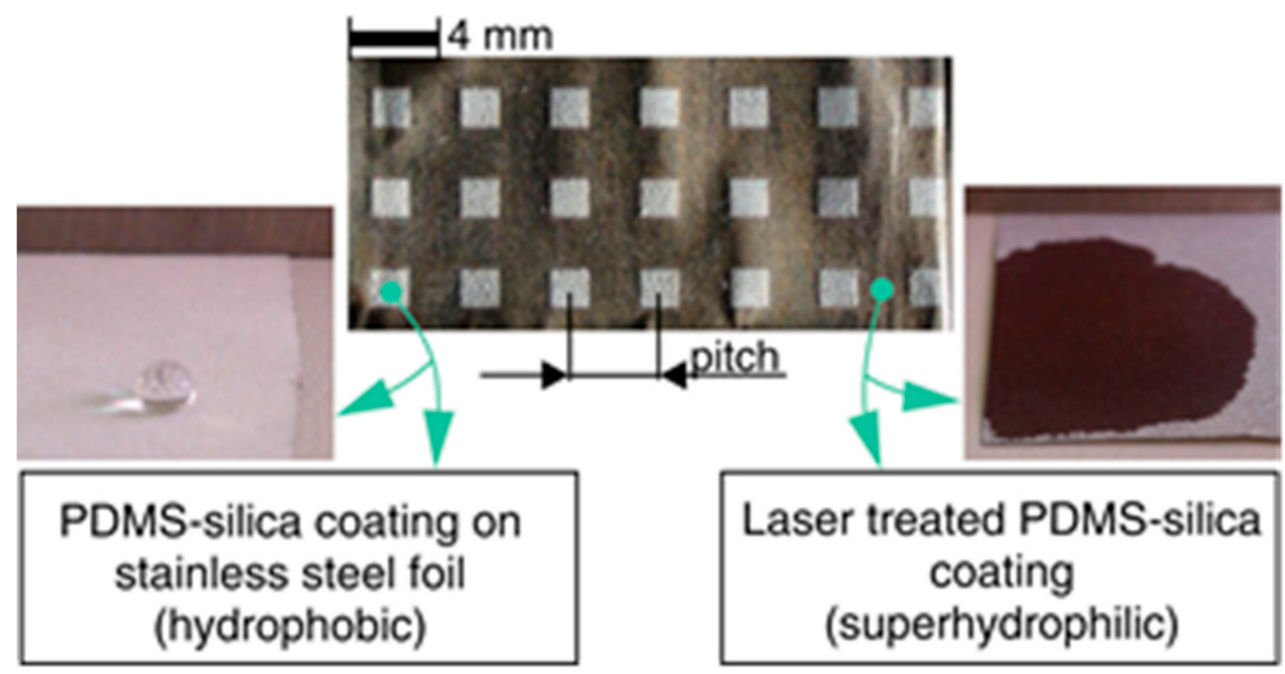

Figure 9. Hydrophilic and hydrophobic coating using pulsed neodymium-doped yttrium aluminum garnet (Nd:YAG) laser technique [129]. 
Table 3. Studies of hydrophilic and hydrophobic coating for boiling heat transfer study.

\begin{tabular}{|c|c|c|c|c|c|}
\hline S. No & Substrate & Coating Material & Coating Technique & $\begin{array}{c}\text { Nature } \\
\text { (Hydrophilic/Hydro-Phobic) }\end{array}$ & Ref. \\
\hline 1 & Heating surface & $\begin{array}{c}\text { Nickel with } \\
\text { polytetrafluoroethylene } \\
\text { (PTFE) particles }\end{array}$ & $\begin{array}{l}\text { Electrolytic nickle } \\
\text { coating with } \\
\text { PTFE particles }\end{array}$ & Hydrophobic & [134] \\
\hline 2 & $\begin{array}{l}\text { Ni Wires } \\
\text { of } 0.25 \mathrm{~mm}\end{array}$ & $\mathrm{PAH} / \mathrm{SiO}_{2}$ & $\begin{array}{l}\text { Layer by layer } \\
\text { assembly method }\end{array}$ & $\begin{array}{l}\text { Hydrophilic, hydrophobic and } \\
\text { super hydrophobic }\end{array}$ & [110] \\
\hline 3 & Stainless-steel foil & $\begin{array}{l}\text { Polydimethylsiloxane-silica } \\
\text { coating }\end{array}$ & Pulsed Nd: YAG laser & $\begin{array}{c}\text { Biphilic } \\
\text { (hydrophobic/superhydrophilic } \\
\text { patterns) }\end{array}$ & [129] \\
\hline 4 & Sapphire substrate & $\begin{array}{c}\mathrm{SiO}_{2} \text { nanoparticles and } \\
\text { monolayer thickness fluoro } \\
\text { silane }\end{array}$ & $\begin{array}{l}\text { Layer by layer } \\
\text { deposition }\end{array}$ & $\begin{array}{c}\text { Hydrophilic and } \\
\text { hydrophobic matrices }\end{array}$ & [136] \\
\hline 5 & Cu substrate & $\begin{array}{l}\text { Teflon layer (hydrophobic), } \\
\mathrm{TiO}_{2} \text { (hydrophilic) }\end{array}$ & $\begin{array}{c}\text { Hydrophobic: } \\
\text { photolithography. } \\
\text { Hydrophilic by two } \\
\text { step process: layer by } \\
\text { layer self-assembly } \\
\text { and liquid } \\
\text { phase deposition }\end{array}$ & $\begin{array}{c}\text { Hydrophobic, hydrophilic and } \\
\text { mixed } \\
\text { hydrophobic/hydrophilic }\end{array}$ & [125] \\
\hline 6 & Stainless-steel & $\begin{array}{l}\text { Silicon oxide and } \\
\text { silicon carbide }\end{array}$ & Pulsed Nd: YAG laser & $\begin{array}{c}\text { Hydrophobic and } \\
\text { superhydrophobic patterns }\end{array}$ & [137] \\
\hline 7 & Copper & $\begin{array}{c}\text { Fe-Doped } \mathrm{Al}_{2} \mathrm{O}_{3}-\mathrm{TiO}_{2} \\
\text { Composite }\end{array}$ & Spray coating & Hydrophilic & [138] \\
\hline 8 & Glass & $\begin{array}{l}\text { Octadecyltrichlorosilane } \\
\text { (OTD) to add hydrophobic } \\
\text { layer }\end{array}$ & $\begin{array}{l}\text { Immersion in ots } \\
\text { mixture }\end{array}$ & Hydrophilic and hydrophobic & [139] \\
\hline 9 & Copper & Cuprous and cupric oxides & Using alkali solution & Hydrophilic surfaces & [140] \\
\hline 10 & $\mathrm{TiO}_{2}$ & Photo-induced wettability & $\begin{array}{l}\text { Ultraviolet light } \\
\text { irradiation }\end{array}$ & Enhanced wettability & [141] \\
\hline 11 & Metal tube & $\mathrm{FeCrAl}$ and $\mathrm{Cr}$ & $\begin{array}{c}\text { Direct current } \\
\text { magnetron sputtering }\end{array}$ & $\begin{array}{l}\text { Hydrophilic and } \\
\text { superhydrophilic }\end{array}$ & [142] \\
\hline
\end{tabular}

\subsection{Micro-Scale Coatings}

Micro scale surfaces result in better heat transfer performance by increasing CHF and by reduction of surface superheat [143-147]. According to different phenomenological theories, this enhancement is attributed to increasing the density of nucleation site, surface area, the capillary effect to assist liquid flow, and vapor escape paths $[148,149]$. Porous and modulated coating layers reduce the resistance of vapor and liquid opposite flow by separation of two phases. Optimal results can be obtained for the surfaces, which can ensure completely separate pathways for liquid and vapors. Figure 10, represents the ability of surface modification for heat boiling heat transfer as collected from experimental data of Litter and Kaviany [148]. They developed porous coating using spherical particles of copper, with an average diameter of $200 \mu \mathrm{m}$, on a copper substrate as shown in Figure 11. They compared the developed porous surfaces with untreated surfaces for pool boiling and reported enhancement of CHF up to 3 times. Hwang and Kaviany [150] studied pool boiling for different $\mathrm{Cu}$ particle diameter (40 to $80 \mu \mathrm{m}$ ), characteristics (hollow or solid particle) and fabrication process (pressed, shaken or loosely packed). In addition to the theoretical study of different configurations, they showed that completely separated liquid and vapor flow paths could result in significant enhancement [148]. Figure 12, represents the $\mathrm{CHF}$ enhancement capability of different surfaces with respect to plain untreated surface (p), deep porous layer coating indicates lower performance as compared to the plain surface, due to its reduced ability of liquid and vapor phase separation during boiling. The highest performance is indicated for the artery-evaporator configuration with the ability to completely separate the vapor and liquid phase. In order to achieve separate pathways for vapor and working liquid Jaikumar and Kandlikar [7] designed new surface geometry. Porous coating has been applied on fin top of copper surfaces. Bubbles were observed to appear on fin top and channel worked as a source of liquid for these vapors. They also reported channel width to depth ratio as an important parameter for the enhancement of the overall process. 


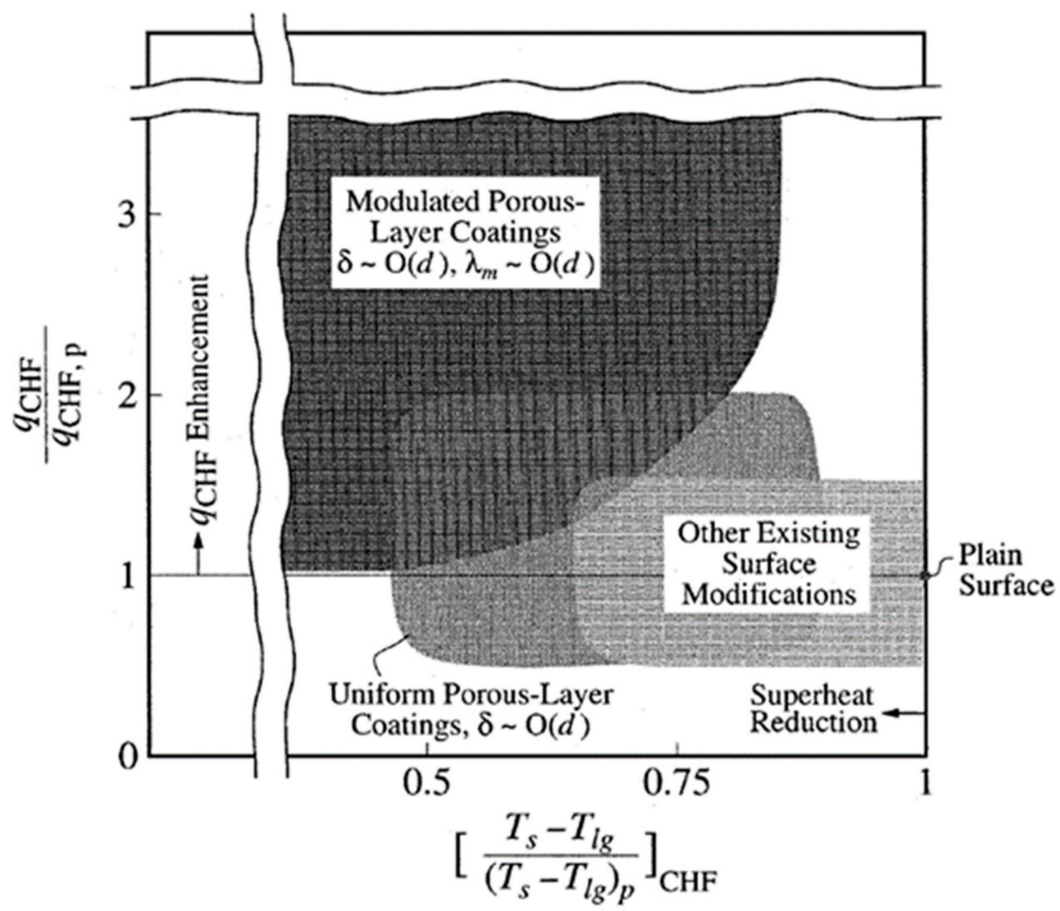

Figure 10. Potential of surface modification for heat transfer [148].
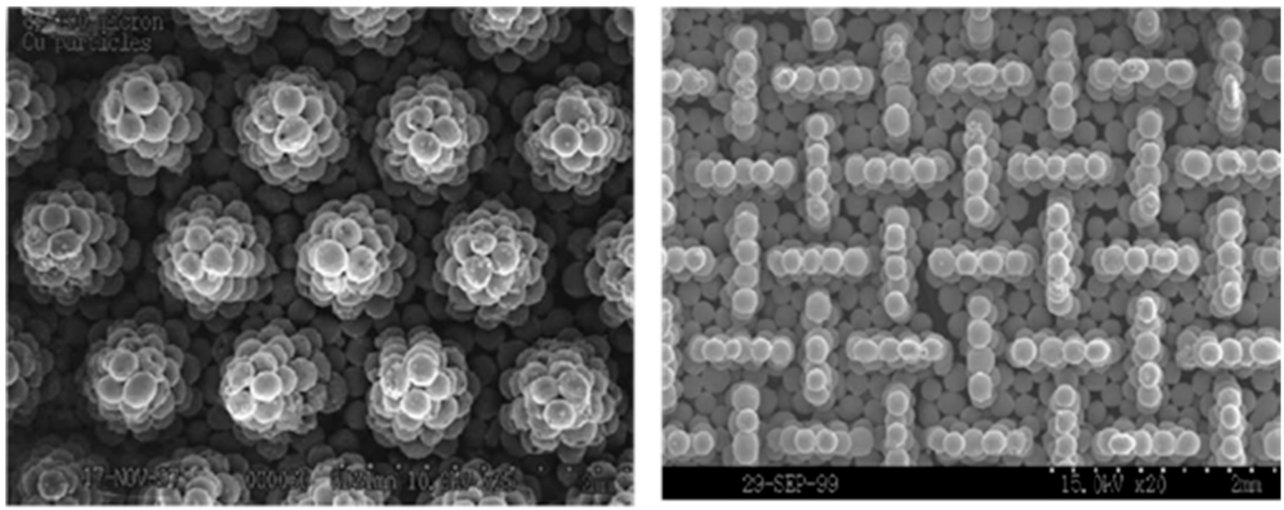

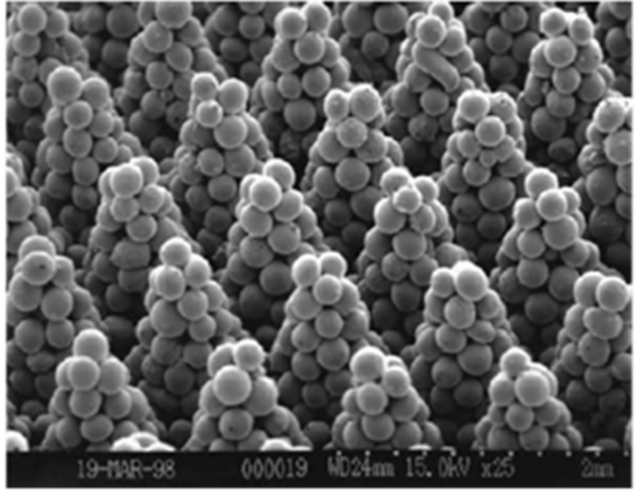

(a)

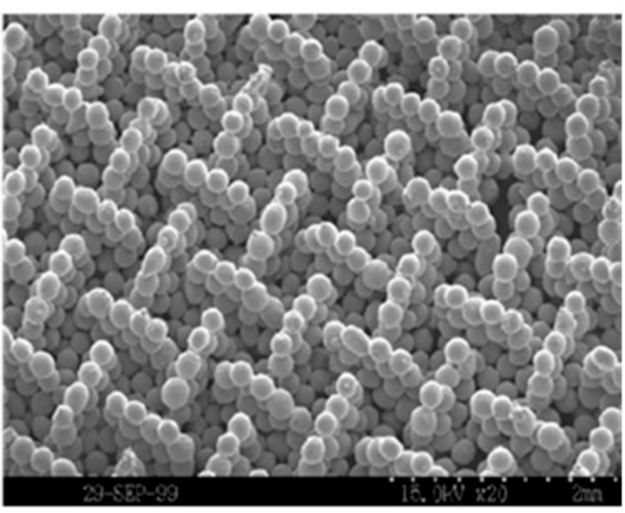

(b)

Figure 11. (a) Conical stacks from $\mathrm{Cu}$ powder with average diameter of $200 \mu \mathrm{m}$ (b) porous layer with Cu particle of $d=200 \mu \mathrm{m}$ (average) with single height (SEM) [148].

Min et al. [151] developed a new method of hot powder compaction for 2-D and 3-D porous coated surfaces with different aspect ratio, pitch (modulation wavelength), particle sizes, and porosity. They reported the strong influence of wavelength and little effect of porosity and particle size on CHF, 
during pool boiling experiments. Maximum enhancement in CHF of coated surfaces was reported 3.3 and 2.0 times higher as compared to plain surfaces. To control the vapor and liquid flow for efficient phase separation, Nasersharifi et al. [152] developed and tested several multilevel modulated wicks such as columnar, monolayer and mushroom posts wicks as shown in Figure 13. The surface was fabricated using $200 \mu \mathrm{m}$ copper particles by multi-step sintering process. The study reported up-to $250 \%$ of improvement in CHF value for n-pentane as working fluid.

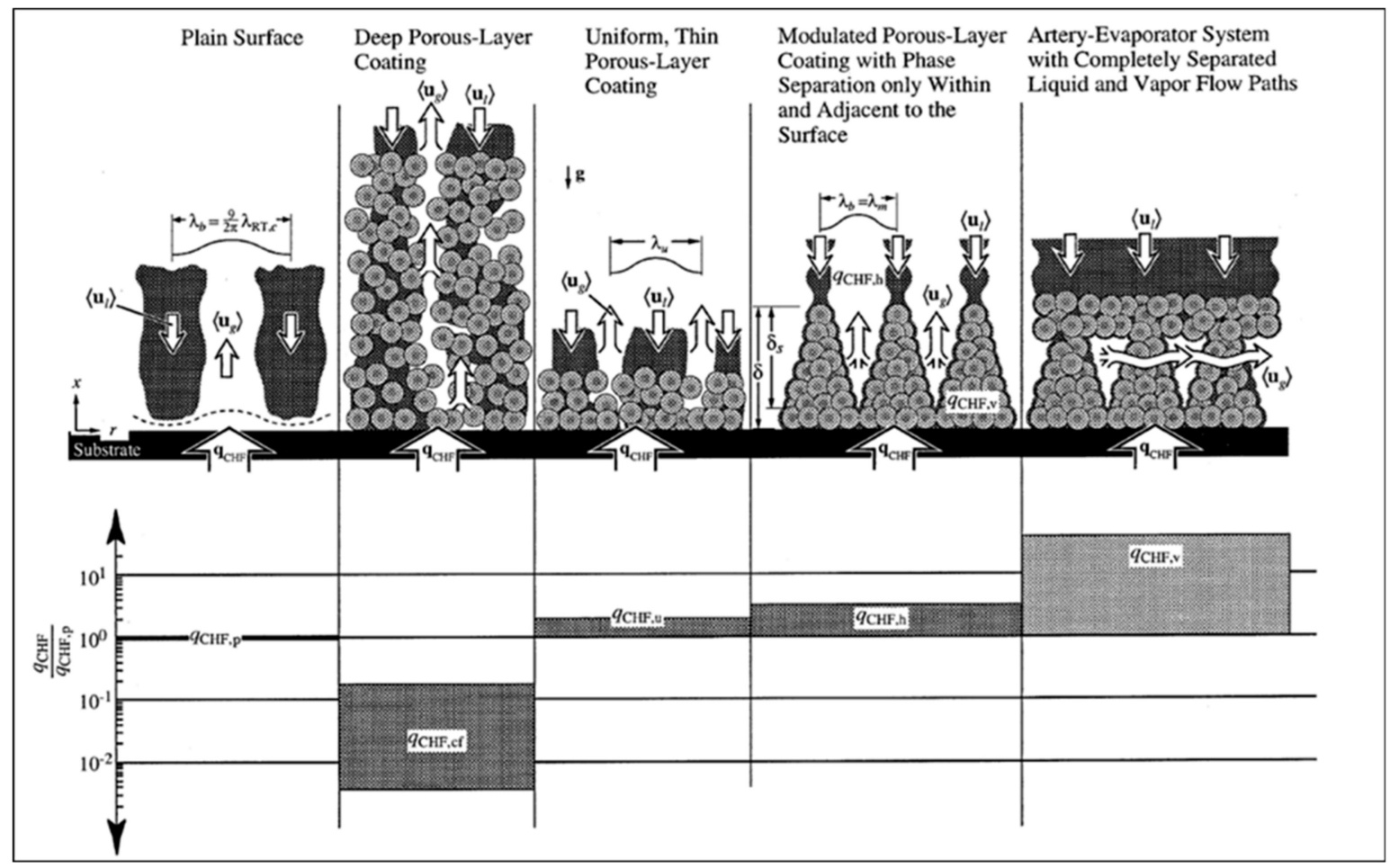

Figure 12. Boiling heat transfer enhancement abilities with different configurations, the $y$-axis represents the increase in the $\mathrm{CHF}$ with respect to plain surface [148].

Similar to particle-based coating, direct coating of foam on the substrate also showed enhanced results for heat transfer enhancement. Yang et al. [153] studied $\mathrm{Cu}$ foam welded on $\mathrm{Cu}$ substrate for pool boiling, shown in Figure 14. They reported the enhancement of CHF pool boiling up to three times and a significant decrease in the onset of nucleate boiling as compared to the plain surface. Similarly, $\mathrm{Xu}$ and Zhao [28] studied $\mathrm{Cu}$ foam with nanoparticles for pool boiling. Coursey et al. [154] applied graphite and reported significantly enhanced results for pool boiling heat transfer experiments for PF-5060 and PF-5050 as working fluids. Wong and Leong [155] developed and tested 3-D printed porous lattice, fabricated by selective laser melting (SLM), for boiling performance. They reported 2.81 times enhancement in HTC as compared to the plain surface. In a similar study, Zhang et al. [156] tested 3-D printed grid structure manufactured by SLM technique. The CHF was reported to be enhanced by 3 times.

Deng et al. $[157,158]$ used solid-state sintering method to develop porous structures with re-entrant cavities (PS-RC). Omega-shaped porous copper powder coating, shown in Figure 15 and Table 4, and solid structure of the same shape and material were prepared for comparison of nucleate boiling heat transfer. They demonstrated significantly improved results for both wall superheat and boiling heat transfer for ethanol and water tests for porous structures. The enhancement was reported due to increase in nucleation sites, overall surface area and enhancement in liquid replenishment.

Hybrid copper nanowires (CuNWs) and microgrooves were fabricated and tested for NBHT by Chen and Li [146]. First, $70 \mathrm{~nm}$ diameter of CuNWs were fabricated in three different heights of $5 \mu \mathrm{m}, 15 \mu \mathrm{m}, 25 \mu \mathrm{m}$ on plain $\mathrm{Cu}$ substrate via anodic aluminum oxide templates. Second, 
microgrooves with different mesh pitches were fabricated to study the modulated wavelength effect on pool boiling CHF. Thirdly, hybrid of these CuNWs and micro-groves were fabricated to obtain two-tier structures. As compared to untreated flat $\mathrm{Cu}$ surface, the two-tier structures resulted in maximum CHF enhancement of $119.3 \%$, followed by microgrooves by $110.5 \%$ and CuNWs by $68.6 \%$. Mori et al. [159] proposed coating of hybrid porous cellulose beads and $\mathrm{TiO} 2$ nanofluid for the enhanced NBHT performance on a curved surface. The study reported 2 times enhancement of CHF. Zhou et al. [160] coated micro-pin-fins topped with nanoparticles, and reported enhanced boiling performance for FC-72 as working fluid. Cao et al. [161] performed a similar study by coating FeMn oxide nanoparticles on silicon micro-pin-fin configuration and reported enhanced CHF and HTC results. Figure 16 represents, the comparative analysis of CHF enhancement using micro-scale coating, among referenced articles.

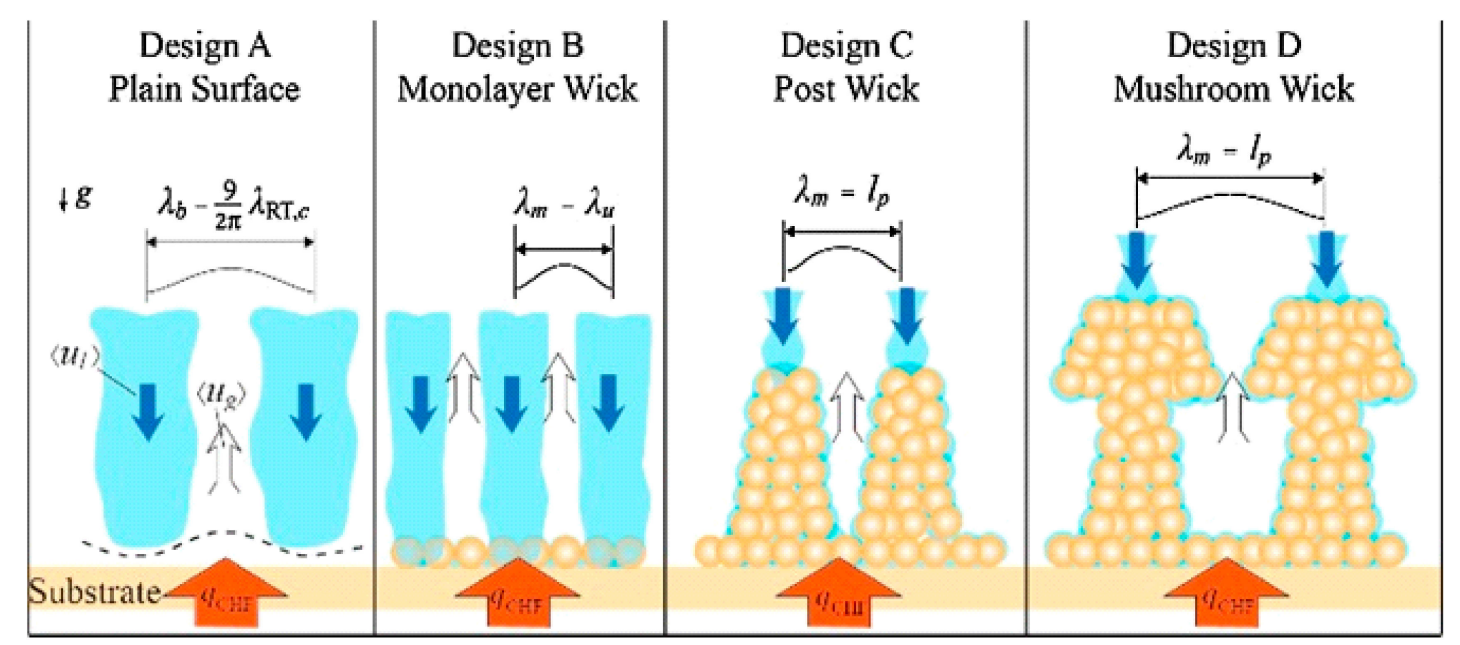

Figure 13. Schematic of multi-level modulated wicks with liquid/vapor flow, wick geometries and hydrodynamic instability wavelengths studied by [152]: (Design A) plain surface; (Design B) monolayer; (Design C) columnar posts; (Design D) mushroom posts wicks [152].

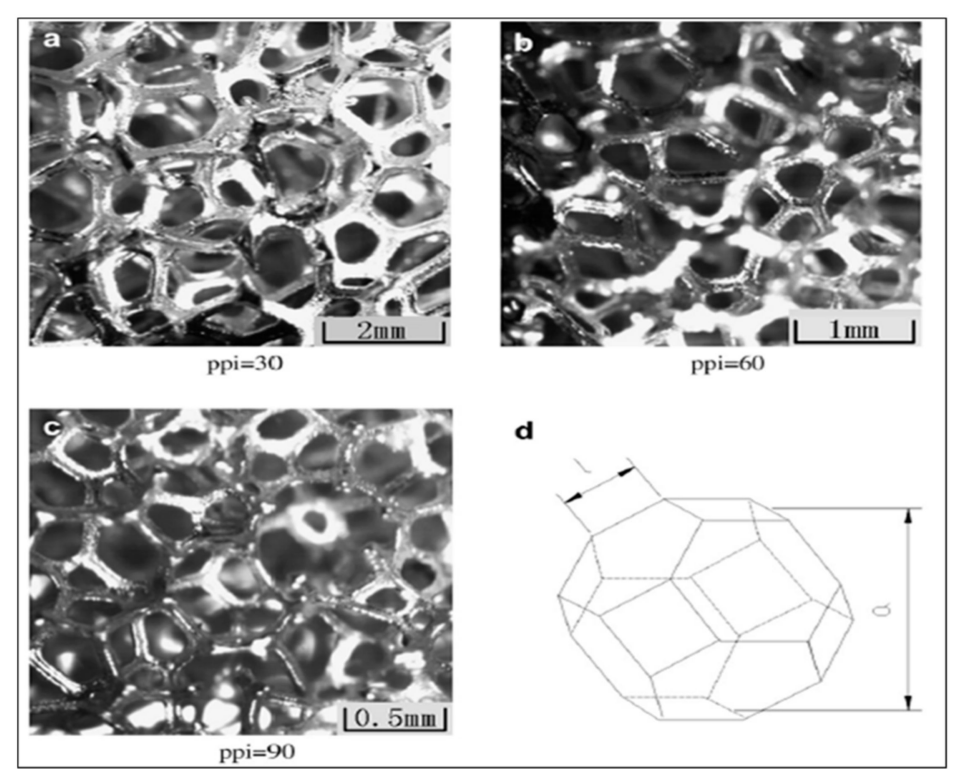

Figure 14. $\mathrm{Cu}$ foam for boiling heat transfer enhancement by [153]. 


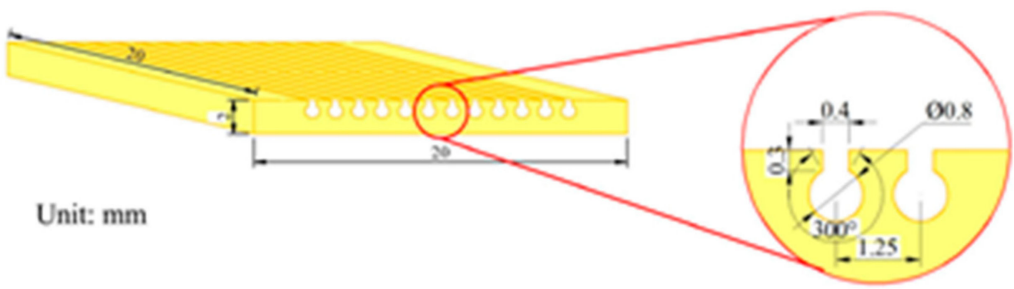

(a)

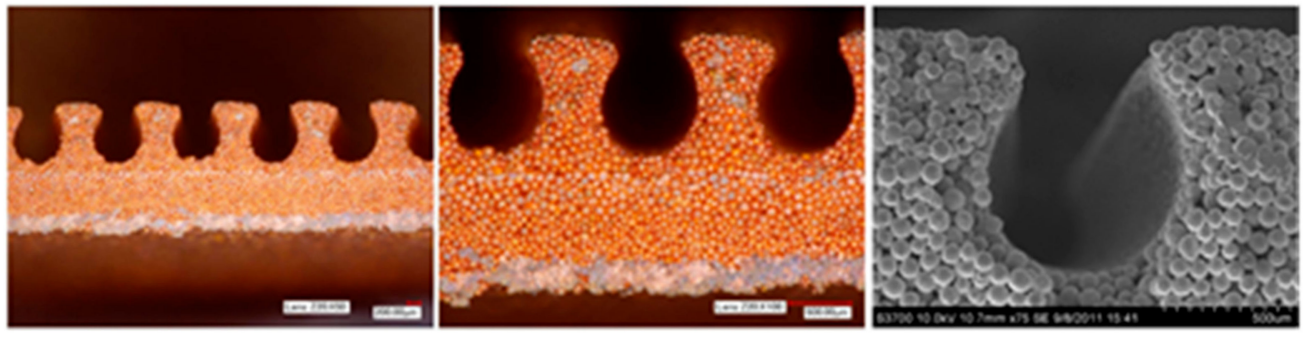

(b)

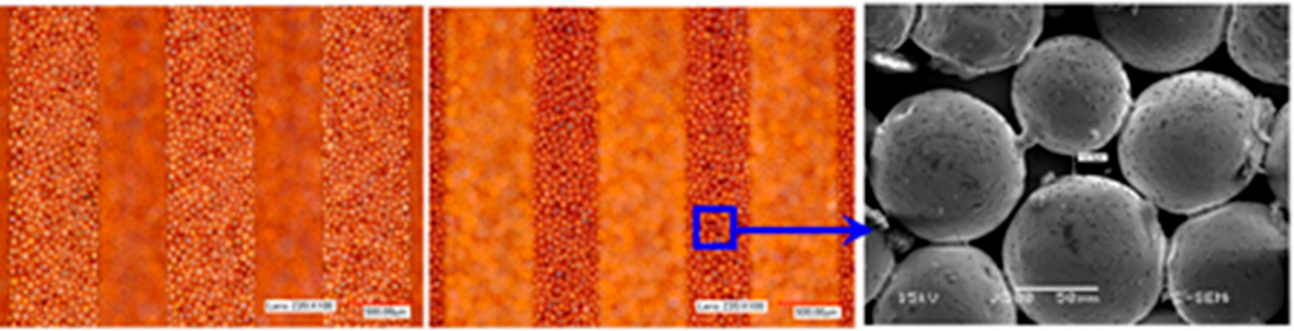

(c)

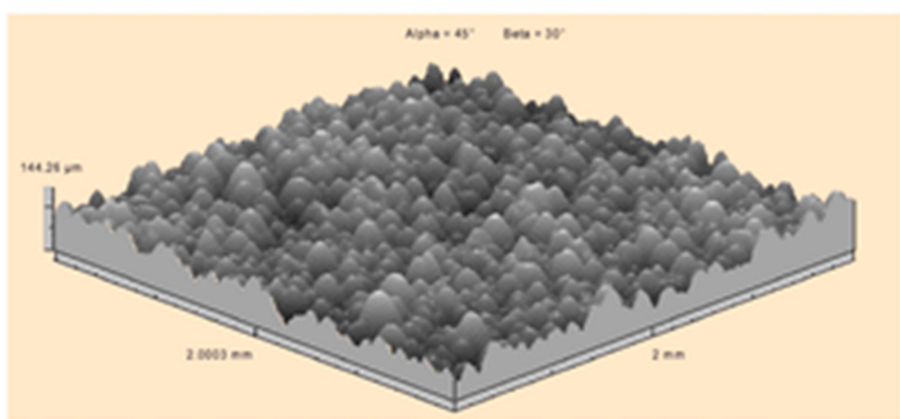

(d)

Figure 15. Re-entrant cavities with porous coating: (a) geometric dimensions; (b) cross-section of coating; (c) top view of coating; (d) profile of the surface [157,158].

Table 4. Porous coating on Surface for boiling heat transfer enhancment.

\begin{tabular}{|c|c|c|c|c|c|c|}
\hline S. No & Substrate & $\begin{array}{c}\text { Coated } \\
\text { Material }\end{array}$ & Geometry & Coating Technique & $\mathrm{CHF}$ & Ref. \\
\hline 1 & Tin & $\begin{array}{c}\text { Metallic } \\
\text { copper foam }\end{array}$ & $\begin{array}{l}\text { V shaped grooved } \\
\text { metallic foam with } \\
\text { porosity of } 0.95 \text { and } \\
\text { thickness } 2 \text { and } 4 \mathrm{~mm} \text {. }\end{array}$ & Binding by Welding & $\begin{array}{l}\text { Enhancement of } \\
\text { CHF } 1.5 \text { times and } \\
\text { HTC } 3 \text { times. }\end{array}$ & [162] \\
\hline 2 & $\begin{array}{c}\text { Porous } \\
\text { structure of } \\
\text { cu particles }\end{array}$ & $\begin{array}{l}\text { Cu particles } \\
\text { of } 250 \mu \mathrm{m} \text { to } \\
400 \mu \mathrm{m}\end{array}$ & $\begin{array}{l}\text { Uniform Thick porous } \\
\text { structures and pillars } \\
\text { porous structures }\end{array}$ & Sintering & $\begin{array}{c}\mathrm{CHF} 450 \mathrm{~W} / \mathrm{Cm}^{2} \text {, } \\
3 \text { times higher to } \\
\text { corresponding plain } \\
\text { surface. And HTC } \\
3 \text { times higher }\end{array}$ & [163] \\
\hline 3 & $\mathrm{Al}$ And $\mathrm{Cu}$ & $\mathrm{ZnO}$ & $\begin{array}{l}\mathrm{ZnO} \text { Nanostructured } \\
\text { on Substrate }\end{array}$ & $\begin{array}{c}\text { Micro } \\
\text { Reactor-Assisted-Nanomaterial- } \\
\text { Deposition (MAND) }\end{array}$ & $\begin{array}{l}\text { CHF: } 82.5 \mathrm{~W} / \mathrm{Cm} 2, \\
\text { 3.5 Times } \\
\text { Enhancement }\end{array}$ & [164] \\
\hline
\end{tabular}


Table 4. Cont.

\begin{tabular}{|c|c|c|c|c|c|c|}
\hline S. No & Substrate & $\begin{array}{l}\text { Coated } \\
\text { Material }\end{array}$ & Geometry & Coating Technique & CHF & Ref. \\
\hline 4 & Silicon & $\mathrm{Cu}$ and $\mathrm{Si}$ & $\begin{array}{l}\text { Nanowires on } \mathrm{Cu} \text { and } \\
\mathrm{Si} \text { Substrate }\end{array}$ & Electroplating and Etching & $\begin{array}{c}\text { CHF: } 192 \text { And } \\
\text { W/Cm2, Enhanced } \\
\text { By } 100 \% .\end{array}$ & [43] \\
\hline 5 & Copper & Cu Particles & $\begin{array}{c}\text { Porous coating of } \\
\text { Cu particles on } \\
\text { Cu Substrate }\end{array}$ & Brazing & CHF: 2.1-fold & [165] \\
\hline 6 & $\mathrm{Cu}$ & Cu Particles & Micro-porous coating & Sintering & $\begin{array}{l}\text { CHF: } 4.5 \text { Times } \\
\text { Higher }\end{array}$ & [53] \\
\hline 7 & $\mathrm{Cu}$ & $\mathrm{Cu}$ Particles & $\begin{array}{c}\text { Hierarchical } \\
\text { micro-porous structures }\end{array}$ & - & $\begin{array}{l}\text { CHF Enhancement: } \\
412 \%\end{array}$ & [166] \\
\hline 8 & $\mathrm{Si}$ & $\begin{array}{l}\text { Diamond } \\
\text { Particles }\end{array}$ & $\begin{array}{c}\text { Diamond Based } \\
\text { Micro-Porous coating } \\
\text { on Si Heater }\end{array}$ & $\begin{array}{l}\text { Diamond-Omega Bond-Acetone } \\
\text { (DOA) Coating }\end{array}$ & $\begin{array}{l}47 \mathrm{~W} / \mathrm{Cm}^{2} \text {, up to } \\
60 \% \text { Enhancement. }\end{array}$ & [167] \\
\hline 9 & $\mathrm{Cu}$ & Alumina & $\begin{array}{l}\text { Porous alumina coating } \\
\text { in a mini channel }\end{array}$ & Spray pyrolysis coatings & $\begin{array}{l}28.3 \% \text { enhancement } \\
\text { in heat flux }\end{array}$ & [168] \\
\hline 11 & Cu Chip & - & $\begin{array}{l}\text { Porous Layers on } \\
\text { micro-channelsFins Top }\end{array}$ & Two step electrodeposition process & Up-to $3250 \mathrm{KW} / \mathrm{m}^{2}$ & [169] \\
\hline 12 & $\mathrm{Cu}$ & $\mathrm{Al}_{2} \mathrm{O}_{3}-\mathrm{TiO}_{2}$ & $\begin{array}{l}\text { Nanostructured } \\
\text { porous surface }\end{array}$ & $\begin{array}{c}\text { Facile hot-dip } \\
\text { galvanizing/dealloying process }\end{array}$ & $\begin{array}{c}\text { CHF and HTC } \\
\text { increased by } 52.39 \% \\
\text { and } 44.11 \% .\end{array}$ & [138] \\
\hline 13 & $\mathrm{Cu}$ & $\begin{array}{l}\text { Porous } \\
\text { graphite }\end{array}$ & $\begin{array}{l}\text { Porous surface with } \\
\text { pores ranges from } \\
1 \text { to } 100 \mu \mathrm{m} .\end{array}$ & - & $\begin{array}{l}\text { Enhanced HTC by } \\
57 \% \text { and CHF } 15 \%\end{array}$ & [170] \\
\hline 14 & $\mathrm{Cu}$ & $\begin{array}{l}\text { Porous } \\
\text { coating }\end{array}$ & $\begin{array}{l}\text { Porous coating on } \\
\text { copper fin top }\end{array}$ & Electrodeposition & $\begin{array}{l}\text { Maximum CHF } \\
\text { enhancement } \\
\text { of } 270 \%\end{array}$ & [7] \\
\hline 15 & $\begin{array}{l}\text { Stainless } \\
\text { steel foil }\end{array}$ & micro-cavities & $\begin{array}{l}\text { Multi-scale } \\
\text { micro-cavities } \\
(0.2 \text { to } 10 \mu \mathrm{m})\end{array}$ & Laser-processed & $\begin{array}{l}\text { HTC increased by } \\
3.7 \text { factor }\end{array}$ & [171] \\
\hline 16 & $\mathrm{Cu}$ & $\begin{array}{l}\text { Cu micro } \\
\text { particles }\end{array}$ & $\begin{array}{c}\text { Micro-nano } \\
\text { bi-porous surface }\end{array}$ & $\begin{array}{l}\text { Hydrogen bubble template } \\
\text { deposition method }\end{array}$ & $\begin{array}{l}\text { HTC increased by } \\
4.8 \text { times }\end{array}$ & [172] \\
\hline 17 & $\mathrm{Si}$ & $\begin{array}{l}\text { Boron } \\
\text { nitride }\end{array}$ & Film coating & Spray coating & $\begin{array}{c}\text { Maximum HTC } \\
\text { enhancement of } \\
160 \%\end{array}$ & [173] \\
\hline 18 & Cu tube & Ag particles & Porous coating & Powder flame spraying technique & $\begin{array}{l}\text { Maximum HTC } \\
\text { increased by } 2 \text { times }\end{array}$ & [174] \\
\hline
\end{tabular}

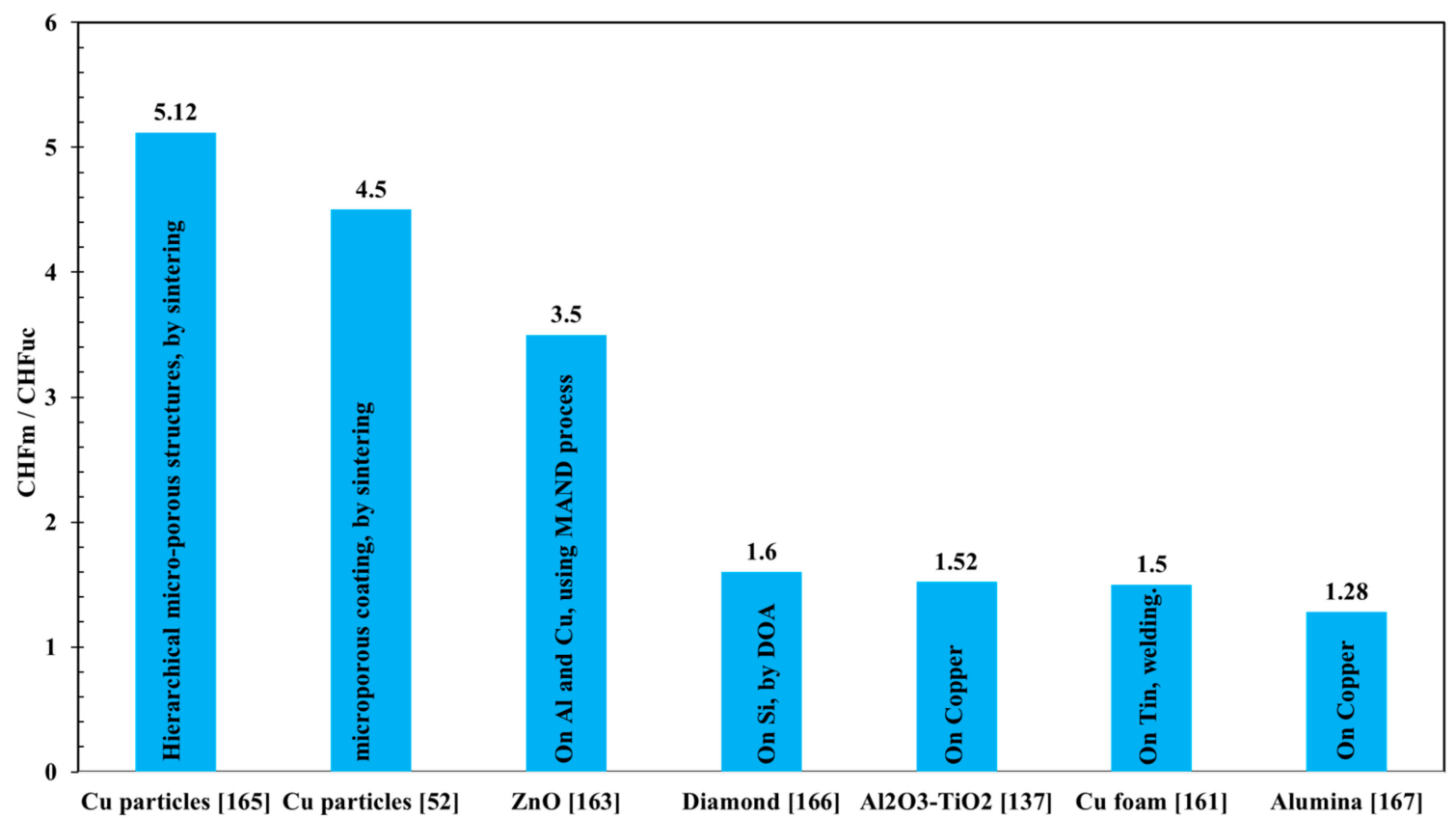

Figure 16. Maximum enhancement of CHF by modification of the substrate with porous coatings. Refer to Table 4, for detailed conditions of the studies listed on the $X$-axis. On Y-axis, " $\mathrm{m}$ " represents coated modified surface and "un" represents the uncoated flat surface. 


\subsection{Carbon Based Nanoparticles Coatings}

Carbon Nano Tubes (CNTs) and Graphene (Gr) have one of the highest thermal conductivity [175-178]. Although lower wettability shifts nucleate boiling towards lower performance region of film boiling, the significant thermal conductivity of these materials overcome this effect and improve overall heat transfer performance $[179,180]$. CNT, graphene oxide (GO) and carbon nano fibers (CNF) are widely reported in the literature for NBHT performance enhancement [181].

Different researchers have studied the effect of single wall and multiwall CNTs for boiling heat transfer for both pool boiling [182-184] and for flow boiling [185,186] and obtained improved results. Seo et al. [187] used stainless steel as a substrate for single-walled CNT and reported 55\% increase in CHF. In the case of CNT on a metal substrate, CNTs acts as hydrophobic dots to increase nucleation points. Bubbles appear to generate on top of these CNT coatings, while the untreated flat metal surface in their surrounding act as a hydrophilic region and helps in delaying film formation [188].

Both direct coatings of CNT on the substrate and its hybrid with other modification methods have been tested by various researchers. Launay et al. [189] developed a hybrid micro-nano scale surface by growing nano-scale CNT's on base surface with pin fins and micro-channels. Chemical vapor deposition (CVD) was used for the growing CNTs on the substrate surface. This combination of micro and nanostructures led to a significant performance increase of up to $100 \%$ enhancement on heat flux. This study also compared different silicon surfaces such as smooth, etched, untreated and fully coated with CNTs and 3D microstructures. Results showed the highest performance for 3D microstructure surfaces for boiling heat transfer using PF5060 and deionized water. Park et al. [190] applied spray coating of oxidized MWCNT and Gr coating, as shown in Figure 17. The contact angle on the substrate was noted to decrease with increasing spray coating time. The decrease in contact angle resulted in an increase in $\mathrm{CHF}$, and maximum HTC appeared at $21.7^{\circ}$ and $19.8^{\circ}$ for $\mathrm{Gr}$ and MWCNTs respectively.

Density and length of CNT's are important parameters for its performance in nucleate boiling. Ahn et al. [191,192] used CVD technique to coat CNTs on the silicon surface. They coated two different heights of $25 \mu \mathrm{m}$ (Type A) and $9 \mu \mathrm{m}$ (Type B). The results were reported for pool boiling experiments in nucleate and film boiling regimes using PF-5060 as working fluid. CHF of CNTs coated surfaces resulted in $25-28 \%$ enhancement as compared to the untreated surface. While in film boiling regime Type-A CNTs showed $57 \%$ higher heat flux and Type B showed no change as compared to the untreated surface. Another similar study was conducted by Bertossi et al. [188] for $3 \mu \mathrm{m}$ to the $10 \mu \mathrm{m}$ length of CNTs. Nucleation points were observed to generate on the top of CNTs due to their hydrophobic nature. The results showed that the higher the length the higher is the heat transfer coefficient and up to $100 \%$ increase was reported in HTC. Ujereh et al. [193] tested Different CNTs arrays and densities, on $\mathrm{Cu}$ and $\mathrm{Si}$ substrate for pool boiling performance. Iron was used as a catalyst for the growth of CNTs in plasma enhanced chemical vapor deposition (PECVD) system. The results showed that CNT coated Si substrate had high CHF and high heat transfer coefficient as compared to the uncoated CNT surface of Si substrate. Efforts were made for the enhancement of the performance by changing the density: the best performance was always achieved for the full dense surface. Cu surface gave better enhancement in performance as compared to the Si substrate because Si surface was comparatively smoother and hence had fewer nucleation points. A trend is expected to be followed in the direction of nanostructures on micro-surfaces modification through CNT's.

Similar to CNT, Gr has received much attention in heat transfer applications because of its unique properties [194]. Jaikumar et al. [195] investigated the boiling performance of GO and Gr coating on $\mathrm{Cu}$ substrate by dip coating. The study described an increase in performance with increase in thickness of the coating. They reported $47 \%$ and $42 \%$ of enhancement in HTC and CHF. In their follow up study, Jaikumar et al. [119] presented combined effect of GO with porous copper particles and reported increase in CHF and HTC values. Rishi et al. [196] compared GO and composite GO-Cu for boiling heat transfer performance. The study reported enhanced performance for composite GO-Cu coating as compared to GO coating. 
Hybrid CNT and Gr nano-structures were investigated by Kumar et al. [197] for NBHT. Heterostructures of $\mathrm{Gr} / \mathrm{CNT}$ were grown on $\mathrm{Cu}$ substrate using PECVD technique. This study reported 155\% enhancement in HTC, $40 \%$ increase in CHF and $62 \%$ reduction in boiling superheat. In another study, Sadaghiani et al. [198] investigated the NBHT performance of CVD-grown 3D foamlike Gr-coated silicon hybrid surface. They investigated the effect of porous structures and foam thickness. Thickness levels from $8 \mathrm{~nm}$ to $55 \mathrm{~nm}$ were considered for testing, and maximum enhancement results of CHF and HTC were reported for $13 \mathrm{~nm}$.

In Table 5, some of the studies in this field are summarized. However, it is worth noting that researchers used different experimental fluids, experimental conditions, and substrate materials; thus these studies cannot be compared, but the trend of the performance enhancement can be noted. Figure 18 represents, the comparative analysis of CHF enhancement using carbon based nanoparticles coating, among referenced articles in this study.

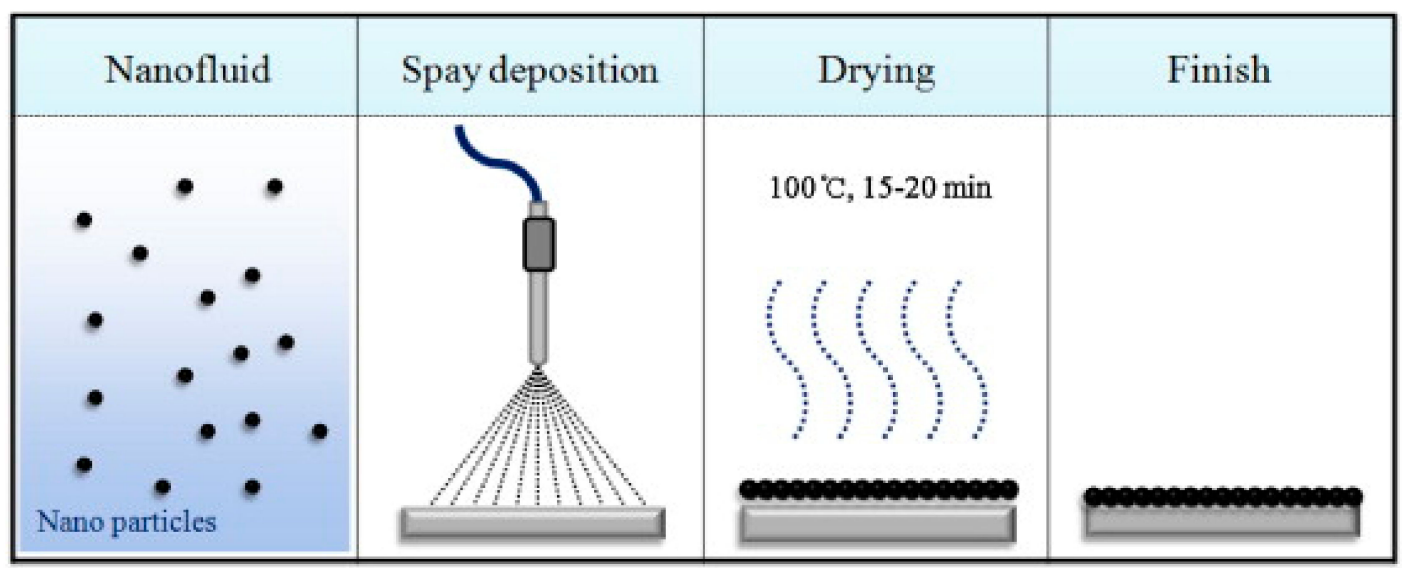

Figure 17. Spray coating of oxidized MWCNT and graphene coating for boiling heat transfer [190].

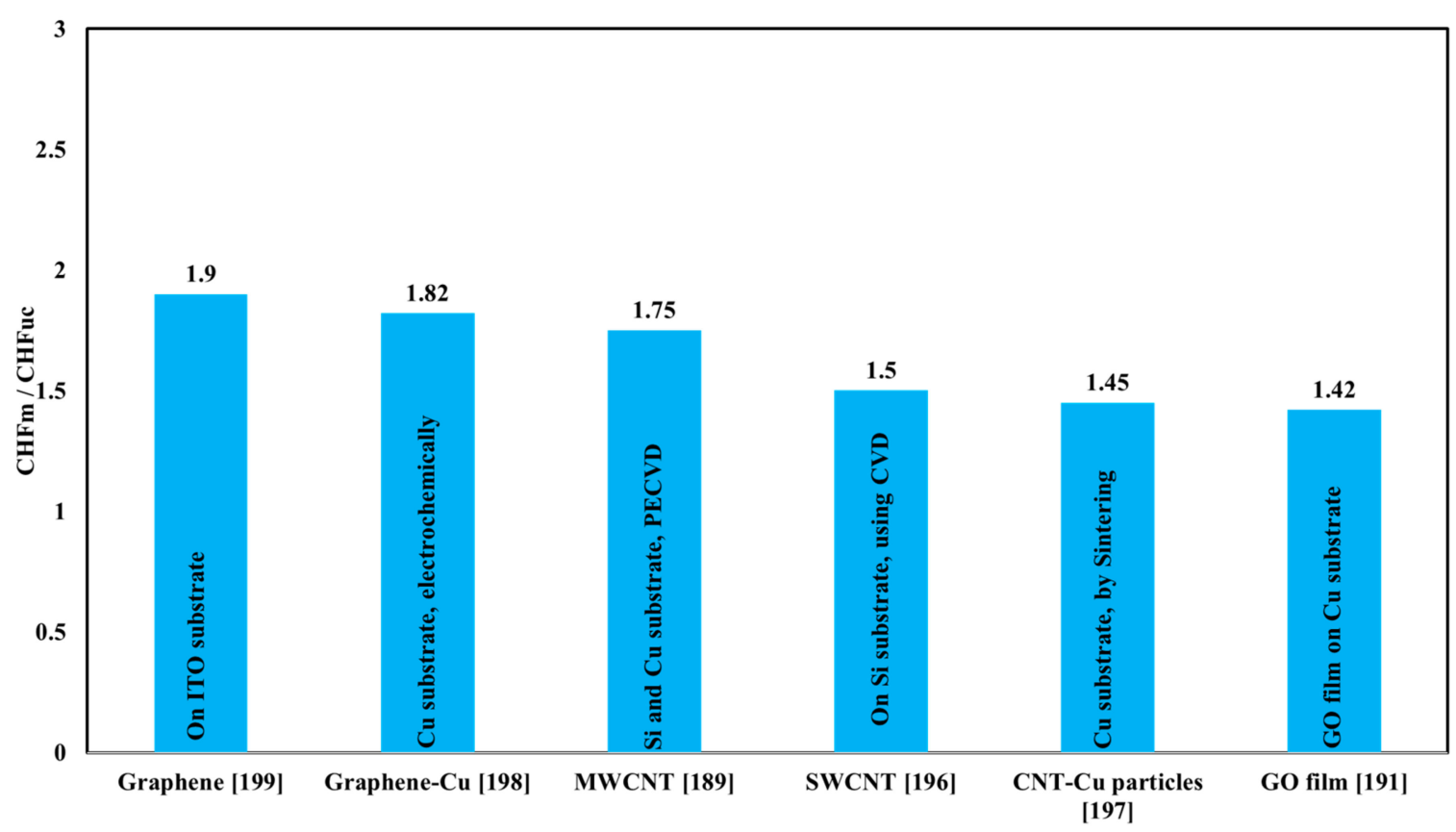

Figure 18. The maximum enhancement of CHF by modification of the substrate with CNT and graphene. Refer to Table 5, for detailed conditions of the studies listed on the $X$-axis. On Y-axis, " $\mathrm{m}$ " represents coated modified surface and "un" represents the uncoated untreated surface. 
Table 5. Carbon nanotubes (CNT) and Graphene coating for boiling heat transfer enhancement.

\begin{tabular}{|c|c|c|c|c|c|c|}
\hline S. No & Material & Geometry & $\begin{array}{c}\text { Experimental Working } \\
\text { Fluid }\end{array}$ & $\begin{array}{l}\text { Manufacturing } \\
\text { Techniques }\end{array}$ & $\begin{array}{l}\text { Heat Transfer } \\
\text { Enhancement } \\
\text { Compared To } \\
\text { Untreated Surface }\end{array}$ & Ref. \\
\hline 1 & $\mathrm{CNT}$ & $\begin{array}{l}\text { CNT growth } \\
\text { on microchannel }\end{array}$ & $\begin{array}{c}\text { Pf5060 and } \\
\text { deionized water }\end{array}$ & CVD & $100 \%$ & [189] \\
\hline 2 & MWCNT & $\begin{array}{l}9 \mu \mathrm{m} \text { and } 25 \mu \mathrm{m} \text { height } \\
\text { and nano diameter }\end{array}$ & Pf-5060 & CVD & $25-28 \%$ & {$[191,192]$} \\
\hline 3 & $\begin{array}{l}\text { CNT, Aln, Sic } \\
\text { On Cu }\end{array}$ & $\begin{array}{l}\text { Porous } \mathrm{Cu}-\mathrm{CNT}-\mathrm{AlN} \\
\text { and } \mathrm{Cu}-\mathrm{CNT}-\mathrm{SiC} \\
\text { composite coatings }\end{array}$ & R134a & $\begin{array}{c}\text { By mechanical alloying } \\
\text { and cold gas } \\
\text { dynamic spraying }\end{array}$ & $\begin{array}{l}\text { Heat transfer } \\
\text { enhancement ratio: } \\
2.83 \text { times and } 2.52 \\
\text { times respectively. }\end{array}$ & [199] \\
\hline 4 & $\mathrm{CNT}$ & $\begin{array}{c}\text { Si surfaces coated with } \\
\text { CNT }\end{array}$ & FC-72 & PECVD & $\begin{array}{l}\text { CHF By } 1.5 \text { times } \\
\text { and HTC by } 400 \%\end{array}$ & [200] \\
\hline 5 & $\begin{array}{l}\mathrm{CNT} \text { and } \\
\text { Cu particles }\end{array}$ & $\begin{array}{c}\mathrm{CNT} \text { and sintered } \\
\text { Cu particles coated on } \\
\text { Cu substrate }\end{array}$ & $\begin{array}{l}\text { Deionized water, } \\
\text { segregated } \\
\text { hydrofluoroether, } \\
\text { Hfe-7300 }\end{array}$ & $\begin{array}{c}\text { Sintering } \\
\text { (for cu particles) }\end{array}$ & $\begin{array}{c}\text { Max. CHF } \\
\text { enhancement } \\
\text { by } 45 \%\end{array}$ & [201] \\
\hline 6 & MWCNTs & $\begin{array}{l}\text { MWCNT On Si And } \\
\text { Cu Substrate }\end{array}$ & FC-72 & PECVD & $\begin{array}{c}\text { CHF } 18.1 \mathrm{~W} / \mathrm{Cm} 2, \\
\text { up-to } 0.75 \%\end{array}$ & [193] \\
\hline 8 & $\mathrm{CNT}$ & $\begin{array}{c}\text { CNT forest of } 3 \text { to } \\
10 \mu \mathrm{m} .\end{array}$ & Water & CVD & $\begin{array}{l}\text { Up-To } 100 \% \text { CHF } \\
\text { enhancement }\end{array}$ & [188] \\
\hline 9 & $\begin{array}{l}\text { SWCNT on } \\
\text { stainless steel } \\
\text { substrate }\end{array}$ & $\begin{array}{c}296,613,845 \text { and } \\
1432 \mathrm{~nm} \text { with roughness } \\
\text { up to } 9.76 \mathrm{~nm}\end{array}$ & Deionized water & SWCNT film adhesion & $\begin{array}{c}\text { 55\% Increase in } \\
\text { CHF but HTC } \\
\text { decreased a little } \\
\text { (due to roughness } \\
\text { decreased). }\end{array}$ & [187] \\
\hline 10 & $\begin{array}{l}\mathrm{Cu} \text { And } \\
\text { graphene }\end{array}$ & $\begin{array}{l}\text { Electrodeposited } \\
\text { Graphene On Cu }\end{array}$ & - & $\begin{array}{c}\text { graphene solution } \\
\text { (electrochemically } \\
\text { obtained) coated on a } \\
\text { copper chip }\end{array}$ & $\begin{array}{l}\text { HTC Increased } \\
\text { By } 82 \%\end{array}$ & [202] \\
\hline 11 & $\begin{array}{l}\text { Graphene, } \\
\text { Sic layers }\end{array}$ & $\begin{array}{c}\text { Graphene, Sic, } \\
\text { deposited On Indium } \\
\text { Tin Oxide (ITO) surface }\end{array}$ & FC-72 & $\begin{array}{l}\text { Graphene: Rta } \\
\text { Sic: PECVD }\end{array}$ & Up-to $90 \%$ & [203] \\
\hline 12 & $\begin{array}{l}\text { Indium tin } \\
\text { oxide (ITO) }\end{array}$ & $\begin{array}{c}\text { Untreated surface, } \\
\text { deposition of graphene } \\
\text { layer on ito and } \\
\text { deposition silicon } \\
\text { carbide (SiC) particles } \\
\text { on ITO }\end{array}$ & FC-72 & - & $\begin{array}{l}\text { Enhancement with } \\
\text { respect to untreated } \\
\text { ITO: graphene layer } \\
9 \% \text { and Sic: } 42 \%\end{array}$ & [204] \\
\hline 13 & CNT & $\mathrm{CNT}$ on $\mathrm{Cu}$ substrate & De-mineralized water & HFCVD & $\begin{array}{l}\text { CHF enhancement } \\
\text { by } 38 \% \\
\end{array}$ & [182] \\
\hline 14 & GO & Film on $\mathrm{Cu}$ substrate & distilled water & Dip coating & $\begin{array}{l}\text { Enhancement in } \\
\text { HTC and CHF by } \\
47 \% \text { and } 42 \%, \\
\text { respectively. }\end{array}$ & [195] \\
\hline 15 & Reduced GO & Coating on Ni-wire & Water-rGO & NBHT & $\begin{array}{c}\text { HEC enhancement } \\
\text { up-to } 245 \%\end{array}$ & [205] \\
\hline
\end{tabular}

\section{Conclusions and Future Recommendations}

This paper presents a comprehensive and critical review of nano-coating techniques for nucleate boiling heat transfer (NBHT) along with an integrated discussion on their physics and related key parameters necessary for enhanced heat transfer characteristics. In addition, it critically analyses the enhancement abilities of pool boiling through these nanocoating techniques along with their limitations that commonly arise from their durability and cost-effectiveness. The physics behind NBHT is not completely understood and still needs further research. However, the review of related literature verifies that surface modification is one of the main variables for NBHT. Microand nano-scale manufacturing technologies offer a wide range of surface coating, enhancement and modification possibilities within industrially applicable boundaries of high productivity, cost-effectiveness, reliability, and durability. Hence, the advancements in manufacturing technologies in these directions have made heat transfer enhancement by surface modification an emerging field in heat transfer research.

As a summary of the critical literature review on nano-coatings and techniques on NBHT, the following conclusions and recommendations can be made. 
- Despite the significant improvements in nucleate pool boiling heat transfer performance mainly through newly developed micro-nano coating materials and techniques, industrial application is still not practical. Emphasis should be given to durability and cost improvements of these nano-coatings, which are the main constraints for their industrial and practical implementations.

- Research should be conducted in order to identify the root cause of the physical mechanism of failure of these nano-coated surfaces, and to how to overcome them.

- Novel manufacturing techniques need to be studied to ensure the cost-effectiveness of nano-coatings and surfaces.

- Hybridization of different techniques should be applied to study the possibilities of enhanced heat transfer results such as a combination of nanoparticles on the microstructured porous coating, and the hybrid of microporous and hydrophilic coatings.

- Surfaces developed at lab scale for NBHT need to be applied and tested under their practical applications. In addition, applications of such passive performance enhanced surfaces need to be explored to make their use more attractive for other applications such as water harvesting, self-cleaning in remote areas, aerospace applications, and heat tubes.

- Although highly efficient methods have been reported in the literature, there is a lack of techno-economic studies for these techniques. Likewise, further studies also need to be carried out on corrosion, erosion and adhesion aspects of these nano-coating materials and techniques for NBHT application.

- A standardized lifetime test needs to be developed for performance assessment to make an easy comparison of these nano-coatings techniques and materials.

Author Contributions: The study has been conducted by S.A.K. under supervision of M.A.A. and M.K.

Funding: The publication of this article was funded by Qatar National Library (QNL).

Conflicts of Interest: The authors declare no conflict of interest.

\section{References}

1. Manglick, R.M. Heat transfer Enhancement. In Heat Transfer Handbook; Bejan, A., Kraus, A.D., Eds.; John Wiley \& Sons, Inc.: Hoboken, NJ, USA, 2003; pp. 1029-1130. ISBN 0-471-39015-1.

2. Betz, A.R.; Xu, J.; Qiu, H.; Attinger, D. Do surfaces with mixed hydrophilic and hydrophobic areas enhance pool boiling? Appl. Phys. Lett. 2010, 97, 14-16. [CrossRef]

3. Zhang, L.; Shoji, M. Nucleation site interaction in pool boiling on the artificial surface. Int. J. Heat Mass Transf. 2003, 46, 513-522. [CrossRef]

4. Ciloglu, D.; Bolukbasi, A. A comprehensive review on pool boiling of nanofluids. Appl. Therm. Eng. 2015, 84, 45-63. [CrossRef]

5. Hetsroni, G.; Zakin, J.; Lin, Z.; Mosyak, A.; Pancallo, E.; Rozenblit, R. The effect of surfactants on bubble growth, wall thermal patterns and heat transfer in pool boiling. Int. J. Heat Mass Transf. 2001, 44, 485-497. [CrossRef]

6. Bartoli, C.; Baffigi, F. Effects of ultrasonic waves on the heat transfer enhancement in subcooled boiling. Exp. Therm. Fluid Sci. 2011, 35, 423-432. [CrossRef]

7. Jaikumar, A.; Kandlikar, S.G. Enhanced pool boiling for electronics cooling using porous fin tops on open microchannels with FC-87. Appl. Therm. Eng. 2015, 91, 426-433. [CrossRef]

8. Kalani, A.; Kandlikar, S.G. Enhanced Pool Boiling with Ethanol at Subatmospheric Pressures for Electronics Cooling. J. Heat Transf. 2013, 135, 111002. [CrossRef]

9. Schubert, A.; Zinecker, M.; Hackert-Oschätzchen, M.; Lausberg, M.; Schulz, A. Application of nucleate boiling with micro structured surfaces for electronic cooling. In Proceedings of the PCIM Europe 2014: International Exhibition and Conference for Power Electronics, Intelligent Motion, Renewable Energy and Energy Management, Nuremberg, Germany, 20-22 May 2014; pp. 1141-1148.

10. Zhang, K.; Liu, Z.; Zheng, B. A new 3D chip cooling technology using micro-channels thermosyphon with super-moist fluids and nanofluids. Energy Convers. Manag. 2016, 128, 44-56. [CrossRef] 
11. Van Gils, R.W.; Danilov, D.; Notten, P.H.L.; Speetjens, M.F.M.; Nijmeijer, H. Battery thermal management by boiling heat-transfer. Energy Convers. Manag. 2014, 79, 9-17. [CrossRef]

12. Chan, C.W.; Siqueiros, E.; Ling-Chin, J.; Royapoor, M.; Roskilly, A.P. Heat utilisation technologies: A critical review of heat pipes. Renew. Sustain. Energy Rev. 2015, 50, 615-627. [CrossRef]

13. Sureshkumar, R.; Mohideen, S.T.; Nethaji, N. Heat transfer characteristics of nanofluids in heat pipes: A review. Renew. Sustain. Energy Rev. 2013, 20, 397-410. [CrossRef]

14. Mohammed, H.A.; Bhaskaran, G.; Shuaib, N.H.; Saidur, R. Heat transfer and fluid flow characteristics in microchannels heat exchanger using nanofluids: A review. Renew. Sustain. Energy Rev. 2011, 15, 1502-1512. [CrossRef]

15. Dixit, T.; Ghosh, I. Review of micro- and mini-channel heat sinks and heat exchangers for single phase fluids. Renew. Sustain. Energy Rev. 2015, 41, 1298-1311. [CrossRef]

16. Mohammed Adham, A.; Mohd-Ghazali, N.; Ahmad, R. Thermal and hydrodynamic analysis of microchannel heat sinks: A review. Renew. Sustain. Energy Rev. 2013, 21, 614-622. [CrossRef]

17. Dong, T. Molecular simulations of R141b boiling flow in micro/nano channel: Interfacial phenomena. Energy Convers. Manag. 2006, 47, 2178-2191. [CrossRef]

18. Paul, G.; Chopkar, M.; Manna, I.; Das, P.K. Techniques for measuring the thermal conductivity of nanofluids: A review. Renew. Sustain. Energy Rev. 2010, 14, 1913-1924. [CrossRef]

19. Zhu, J.; Luo, Y.; Tian, J.; Li, J.; Gao, X. Clustered Ribbed-Nanoneedle Structured Copper Surfaces with High-Efficiency Dropwise Condensation Heat Transfer Performance. ACS Appl. Mater. Interfaces 2015, 7, 10660-10665. [CrossRef] [PubMed]

20. Oberli, L.; Caruso, D.; Hall, C.; Fabretto, M.; Murphy, P.J.; Evans, D. Condensation and freezing of droplets on superhydrophobic surfaces. Adv. Colloid Interface Sci. 2014, 210, 47-57. [CrossRef] [PubMed]

21. Qi, B.; Zhou, J.; Wei, J.; Li, X. Study on the wettability and condensation heat transfer of sine-shaped micro-grooved surfaces. Exp. Therm. Fluid Sci. 2018, 90, 28-36. [CrossRef]

22. Zhao, Y.; Luo, Y.; Zhu, J.; Li, J.; Gao, X. Copper-Based Ultrathin Nickel Nanocone Films with High-Efficiency Dropwise Condensation Heat Transfer Performance. ACS Appl. Mater. Interfaces 2015, 7, 11719-11723. [CrossRef] [PubMed]

23. Yang, F.; Dai, X.; Peles, Y.; Cheng, P.; Khan, J.; Li, C. Flow boiling phenomena in a single annular flow regime in microchannels (I): Characterization of flow boiling heat transfer. Int. J. Heat Mass Transf. 2014, 68, 703-715. [CrossRef]

24. Yarin, L.P.; Mosyak, A.; Hetsroni, G. Fluid Flow, Heat Transfer and Boiling in Micro-Channels; Heat and Mass Transfer; Springer: Berlin/Heidelberg, Germany, 2009; ISBN 978-3-540-78754-9.

25. Abou-ziyan, H.Z. Forced convection and subcooled flow boiling heat transfer in asymmetrically heated ducts of T-section. Energy Convers. Manag. 2004, 45, 1043-1065. [CrossRef]

26. Sedmak, I.; Urbančič, I.; Podlipec, R.; Štrancar, J.; Mortier, M.; Golobič, I. Submicron thermal imaging of a nucleate boiling process using fluorescence microscopy. Energy 2016, 109, 436-445. [CrossRef]

27. Kim, D.E.; Yu, D.I.; Jerng, D.W.; Kim, M.H.; Ahn, H.S. Review of boiling heat transfer enhancement on micro/nanostructured surfaces. Exp. Therm. Fluid Sci. 2015, 66, 173-196. [CrossRef]

28. Xu, Z.G.; Zhao, C.Y. Influences of nanoparticles on pool boiling heat transfer in porous metals. Appl. Therm. Eng. 2014, 65, 34-41. [CrossRef]

29. Jothi Prakash, C.G.; Prasanth, R. Enhanced boiling heat transfer by nano structured surfaces and nanofluids. Renew. Sustain. Energy Rev. 2018, 82, 4028-4043. [CrossRef]

30. Revellin, R.; Lips, S.; Khandekar, S.; Bonjour, J. Local entropy generation for saturated two-phase flow. Energy 2009, 34, 1113-1121. [CrossRef]

31. Bergman, T.L.; Incropera, F.P.; DeWitt, D.P.; Lavine, A.S. Fundamentals of Heat and Mass Transfer; John Wiley \& Sons: Hoboken, NJ, USA, 2011.

32. Georgoulas, A.; Andredaki, M.; Marengo, M. An enhanced VOF method coupled with heat transfer and phase change to characterise bubble detachment in saturated pool boiling. Energies 2017, 10, 272. [CrossRef]

33. Mohanty, R.L.; Das, M.K. A critical review on bubble dynamics parameters influencing boiling heat transfer. Renew. Sustain. Energy Rev. 2017, 78, 466-494. [CrossRef]

34. Attinger, D.; Frankiewicz, C.; Betz, A.R.; Schutzius, T.M.; Ganguly, R.; Das, A.; Kim, C.-J.; Megaridis, C.M. Surface engineering for phase change heat transfer: A review. MRS Energy Sustain. 2014, 1, E4. [CrossRef] 
35. Han, Y.; Palacios, J. Latent Heat and Liquid Water Content (LWC) Sensor based on Transient Heat Flux Measurements. In 2018 Atmospheric and Space Environments Conference; American Institute of Aeronautics and Astronautics: Reston, VA, USA, 2018.

36. Mikic, B.; Rohsenow, W.; Griffith, P. On bubble growth rates. Int. J. Heat Mass Transf. 1970, 13, 657-666. [CrossRef]

37. Snyder, N.R.; Edwards, D.K. Summary of Conference on Bubble Dynamics and Boiling Heat Transfer; Jet Propulsion Lab: Pasadena, CA, USA, 1956; p. Memo 20-137.

38. Moore, F.D.; Mesler, R.B. The measurement of rapid surface temperature fluctuations during nucleate boiling of water. AIChE J. 1961, 7, 620-624. [CrossRef]

39. Hendricks, R.C.; Sharp, R.R. Initiation of Cooling Due to Bubble Growth on a Heating Surface; NASA: Washington, DC, USA, 1964.

40. Stephan, P.; Hammer, J. A new model for nucleate boiling heat transfer. Wärme-und Stoffübertragung 1994, 30, 119-125. [CrossRef]

41. Kim, J. Review of nucleate pool boiling bubble heat transfer mechanisms. Int. J. Multiph. Flow 2009, 35, 1067-1076. [CrossRef]

42. Nukiyama, $\mathrm{S}$. The maximum and minimum values of the heat $\mathrm{Q}$ transmitted from metal to boiling water under atmospheric pressure. Int. J. Heat Mass Transf. 1966, 9, 1419-1433. [CrossRef]

43. Chen, R.; Lu, M.-C.; Srinivasan, V.; Wang, Z.; Cho, H.H.; Majumdar, A. Nanowires for Enhanced Boiling Heat Transfer. Nano Lett. 2009, 9, 548-553. [CrossRef] [PubMed]

44. Zuber, N. Hydrodynamic Aspects of Boiling Heat Transfer (Thesis); Ramo-Wooldridge Corp.: Los Angeles, CA, USA; University of California: Los Angeles, CA, USA, 1959.

45. Kutateladze, S.S. On the transition to film boiling under natural convection. Kotloturbostroenie 1948, 3, $152-158$.

46. Collado, F. The law of stable equilibrium and the entropy-based boiling curve for flow boiling. Energy 2005, 30, 807-819. [CrossRef]

47. Tiwari, G.N.; Prakash, O.; Kumar, S. Evaluation of convective heat and mass transfer for pool boiling of sugarcane juice. Energy Convers. Manag. 2004, 45, 171-179. [CrossRef]

48. Liang, G.; Mudawar, I. Pool boiling critical heat flux (CHF)—Part 1: Review of mechanisms, models, and correlations. Int. J. Heat Mass Transf. 2018, 117, 1352-1367. [CrossRef]

49. Liang, G.; Mudawar, I. Pool boiling critical heat flux (CHF)—Part 2: Assessment of models and correlations. Int. J. Heat Mass Transf. 2018, 117, 1368-1383. [CrossRef]

50. Kandlikar, S.G. A Theoretical Model to Predict Pool Boiling CHF Incorporating Effects of Contact Angle and Orientation. J. Heat Transf. 2001, 123, 1071. [CrossRef]

51. Ho, J.Y.; Wong, K.K.; Leong, K.C.; Yang, C. Enhanced Nucleate Pool Boiling from Microstructured Surfaces Fabricated by Selective Laser Melting. In Proceedings of the ASME 2016 5th International Conference on Micro/Nanoscale Heat and Mass Transfer, Volume 1: Micro/Nanofluidics and Lab-on-a-Chip; Nanofluids; Micro/Nanoscale Interfacial Transport Phenomena; Micro/Nanoscale Boiling and Condensation Heat Transfer; Micro/Nanoscale Thermal Radiation; Micro/Nanoscale Energy Devices and Systems, Biopolis, Singapore, 4-6 January 2016; p. V001T04A008.

52. Khan, S.A.; Ali, A.; Hussien, M.A.; Koc, M. Critical Review of Micro-Nano Scale Surface Modification for Phase Change Heat Transfer. In Proceedings of the SEEP 2017-10th International Conference on Sustainable Energy \& Environmental Protection, Bled, Slovenia, 27-30 June 2017; pp. 27-30.

53. Jun, S.; Kim, J.; You, S.M.; Kim, H.Y. Effect of heater orientation on pool boiling heat transfer from sintered copper microporous coating in saturated water. Int. J. Heat Mass Transf. 2016, 103, 277-284. [CrossRef]

54. An, S.; Kim, D.-Y.; Lee, J.-G.; Jo, H.S.; Kim, M.; Al-Deyab, S.S.; Choi, J.; Yoon, S.S. Supersonically sprayed reduced graphene oxide film to enhance critical heat flux in pool boiling. Int. J. Heat Mass Transf. 2016, 98, 124-130. [CrossRef]

55. Das, S.; Kumar, D.S.; Bhaumik, S. Experimental study of nucleate pool boiling heat transfer of water on silicon oxide nanoparticle coated copper heating surface. Appl. Therm. Eng. 2016, 96, 555-567. [CrossRef]

56. Protich, Z.; Santhanam, K.S.V.; Jaikumar, A.; Kandlikar, S.G.; Wong, P. Electrochemical Deposition of Copper in Graphene Quantum Dot Bath: Pool Boiling Enhancement. J. Electrochem. Soc. 2016, 163, E166-E172. [CrossRef]

57. Murshed, S.M.S.; Vereen, K.; Strayer, D.; Kumar, R. An experimental investigation of bubble nucleation of a refrigerant in pressurized boiling flows. Energy 2010, 35, 5143-5150. [CrossRef] 
58. Zhang, X.; Zhang, J.; Ji, H.; Zhao, D. Heat transfer enhancement and pressure drop performance for R417A flow boiling in internally grooved tubes. Energy 2015, 86, 446-454. [CrossRef]

59. Şişman, Y.; Khalili Sadaghiani, A.; Khedir, K.R.; Karabacak, T.; Koşar, A. Nucleate Boiling Heat Transfer Enhancement Using Nanostructured Al-Alloy Plates. In Proceedings of the ASME 2016 5th International Conference on Micro/Nanoscale Heat and Mass Transfer, Volume 2: Micro/Nano-Thermal Manufacturing and Materials Processing; Boiling, Quenching and Condensation Heat Transfer on Engineered Surfaces; Computational Methods in Micro/Nanoscale Transport; Heat and Mass Transfer in Small Scale; Micro/Miniature Multi, Singapore, 4-6 January 2016; p. V002T08A003.

60. Kruse, C.M.; Anderson, T.; Wilson, C.; Zuhlke, C.; Alexander, D.; Gogos, G.; Ndao, S. Enhanced pool-boiling heat transfer and critical heat flux on femtosecond laser processed stainless steel surfaces. Int. J. Heat Mass Transf. 2015, 82, 109-116. [CrossRef]

61. Park, Y.; Kim, H.; Kim, J.; Kim, H. Measurement of liquid-vapor phase distribution on nano- and microstructured boiling surfaces. Int. J. Multiph. Flow 2016, 81, 67-76. [CrossRef]

62. Westwater, J.W. Boiling Heat transfer. Sigma Xi Sci. Res. Soc. 1959, 47, 427-446. [CrossRef]

63. Clark, H.B.; Strenge, P.S.; Westwater, J.W. Active sites for nucleate boiling. Chem. Eng. Progr. 1960, 55, $103-110$.

64. Bankoff, S.G. Ebullition from solid surfaces in the absence of a pre-existing gaseous phase. Trans. Am. Soc. Mech. Eng. 1957, 79, 39-45.

65. Bankoff, S.G. Entrapment of gas in the spreading of a liquid over a rough surface. AIChE J. 1958, 4, $24-26$. [CrossRef]

66. Griffith, P.; Wallis, J.D. The Role of Surface Conditions in Nucleate Boiling; The Role of Surface Conditions in Nucleate Boiling: Cambridge, MA, USA, 1958; pp. 1-32.

67. Shin, S.; Choi, G.; Kim, B.S.; Cho, H.H. Flow boiling heat transfer on nanowire-coated surfaces with highly wetting liquid. Energy 2014, 76, 428-435. [CrossRef]

68. Liang, G.; Mudawar, I. Review of pool boiling enhancement by surface modification. Int. J. Heat Mass Transf. 2019, 128, 892-933. [CrossRef]

69. Jenkins, R.; Lupoi, R.; Kempers, R.; Robinson, A.J. Heat transfer performance of boiling jet array impingement on micro-grooved surfaces. Exp. Therm. Fluid Sci. 2017, 80, 293-304. [CrossRef]

70. Sommers, A.D.; Yerkes, K.L. Using micro-structural surface features to enhance the convective flow boiling heat transfer of R-134a on aluminum. Int. J. Heat Mass Transf. 2013, 64, 1053-1063. [CrossRef]

71. Ahn, H.S.; Park, G.; Kim, J.M.; Kim, J.; Kim, M.H. The effect of water absorption on critical heat flux enhancement during pool boiling. Exp. Therm. Fluid Sci. 2012, 42, 187-195. [CrossRef]

72. Ahn, H.S.; Lee, C.; Kim, J.; Kim, M.H. The effect of capillary wicking action of micro/nano structures on pool boiling critical heat flux. Int. J. Heat Mass Transf. 2012, 55, 89-92. [CrossRef]

73. Ahn, H.S.; Lee, C.; Kim, H.; Jo, H.; Kang, S.; Kim, J.; Shin, J.; Kim, M.H. Pool boiling CHF enhancement by micro/nanoscale modification of zircaloy-4 surface. Nucl. Eng. Des. 2010, 240, 3350-3360. [CrossRef]

74. Chen, S.-W.; Hsieh, J.-C.; Chou, C.-T.; Lin, H.-H.; Shen, S.-C.; Tsai, M.-J. Experimental investigation and visualization on capillary and boiling limits of micro-grooves made by different processes. Sens. Actuators A Phys. 2007, 139, 78-87. [CrossRef]

75. Mitrovic, J. How to create an efficient surface for nucleate boiling? Int. J. Therm. Sci. 2006, 45, 1-15. [CrossRef]

76. Kamatchi, R.; Venkatachalapathy, S. Parametric study of pool boiling heat transfer with nanofluids for the enhancement of critical heat flux: A review. Int. J. Therm. Sci. 2015, 87, 228-240. [CrossRef]

77. Zhang, M.; Lian, K. Using bulk micromachined structures to enhance pool boiling heat transfer. Microsyst. Technol. 2008, 14, 1499-1505. [CrossRef]

78. Solangi, K.H.; Kazi, S.N.; Luhur, M.R.; Badarudin, A.; Amiri, A.; Sadri, R.; Zubir, M.N.M.; Gharehkhani, S.; Teng, K.H. A comprehensive review of thermo-physical properties and convective heat transfer to nanofluids. Energy 2015, 89, 1065-1086. [CrossRef]

79. Bianco, V.; Manca, O.; Nardini, S. Performance analysis of turbulent convection heat transfer of $\mathrm{Al} 2 \mathrm{O} 3$ water-nanofluid in circular tubes at constant wall temperature. Energy 2014, 77, 403-413. [CrossRef]

80. Asirvatham, L.G.; Vishal, N.; Gangatharan, S.K.; Lal, D.M. Experimental Study on Forced Convective Heat Transfer with Low Volume Fraction of CuO/Water Nanofluid. Energies 2009, 2, 97-110. [CrossRef]

81. Wu, W.-T.; Massoudi, M.; Yan, H. Heat Transfer and Flow of Nanofluids in a Y-Type Intersection Channel with Multiple Pulsations: A Numerical Study. Energies 2017, 10, 492. [CrossRef] 
82. Patil, M.; Seo, J.-H.; Kang, S.-J.; Lee, M.-Y. Review on Synthesis, Thermo-Physical Property, and Heat Transfer Mechanism of Nanofluids. Energies 2016, 9, 840. [CrossRef]

83. Li, Y.; Yan, H.; Massoudi, M.; Wu, W.-T. Effects of Anisotropic Thermal Conductivity and Lorentz Force on the Flow and Heat Transfer of a Ferro-Nanofluid in a Magnetic Field. Energies 2017, 10, 1065. [CrossRef]

84. You, S.M.; Kim, J.H.; Kim, K.H. Effect of nanoparticles on critical heat flux of water in pool boiling heat transfer. Appl. Phys. Lett. 2003, 83, 3374. [CrossRef]

85. Vassallo, P.; Kumar, R.; D'Amico, S. Pool boiling heat transfer experiments in silica-water nano-fluids. Int. J. Heat Mass Transf. 2004, 47, 407-411. [CrossRef]

86. Kim, H. Enhancement of critical heat flux in nucleate boiling of nanofluids: A state-of-art review. Nanoscale Res. Lett. 2011, 6, 415. [CrossRef] [PubMed]

87. Kim, H.; Kim, J.; Kim, M.H. Effect of nanoparticles on CHF enhancement in pool boiling of nano-fluids. Int. J. Heat Mass Transf. 2006, 49, 5070-5074. [CrossRef]

88. Kim, S.J.; Bang, I.C.; Buongiorno, J.; Hu, L.W. Effects of nanoparticle deposition on surface wettability influencing boiling heat transfer in nanofluids. Appl. Phys. Lett. 2006, 89, 153107. [CrossRef]

89. Wen, D. Mechanisms of thermal nanofluids on enhanced critical heat flux (CHF). Int. J. Heat Mass Transf. 2008, 51, 4958-4965. [CrossRef]

90. Kim, S.J.; Bang, I.C.; Buongiorno, J.; Hu, L.W. Surface wettability change during pool boiling of nanofluids and its effect on critical heat flux. Int. J. Heat Mass Transf. 2007, 50, 4105-4116. [CrossRef]

91. Jeong, Y.H.; Chang, W.J.; Chang, S.H. Wettability of heated surfaces under pool boiling using surfactant solutions and nano-fluids. Int. J. Heat Mass Transf. 2008, 51, 3025-3031. [CrossRef]

92. Liu, Z.; Liao, L. Sorption and agglutination phenomenon of nanofluids on a plain heating surface during pool boiling. Int. J. Heat Mass Transf. 2008, 51, 2593-2602. [CrossRef]

93. Golubovic, M.N.; Madhawa Hettiarachchi, H.D.; Worek, W.M.; Minkowycz, W.J. Nanofluids and critical heat flux, experimental and analytical study. Appl. Therm. Eng. 2009, 29, 1281-1288. [CrossRef]

94. Watanabe, Y.; Enoki, K.; Okawa, T. Nanoparticle layer detachment and its influence on the heat transfer characteristics in saturated pool boiling of nanofluids. Int. J. Heat Mass Transf. 2018, 125, 171-178. [CrossRef]

95. Das, S.K.; Putra, N.; Roetzel, W. Pool boiling characteristics of nano-fluids. Int. J. Heat Mass Transf. 2003, 46, 851-862. [CrossRef]

96. Das, S.K.; Putra, N.; Roetzel, W. Pool boiling of nano-fluids on horizontal narrow tubes. Int. J. Multiph. Flow 2003, 29, 1237-1247. [CrossRef]

97. Wen, D.; Ding, Y. Experimental investigation into convective heat transfer of nanofluids at the entrance region under laminar flow conditions. Int. J. Heat Mass Transf. 2004, 47, 5181-5188. [CrossRef]

98. Kim, H.; Kim, M. Experimental study of the characteristics and mechanism of pool boiling CHF enhancement using nanofluids. Heat Mass Transf. 2009, 45, 991-998. [CrossRef]

99. Kim, S.J.; Bang, I.C.; Buongiomo, J.; Hu, L.W. Study of pool boiling and critical heat flux enhancement in nanofluids. Bull. Pol. Acad. Sci. Tech. Sci. 2007, 55, 211-216.

100. Iida, Y.; Tsuyuki, T.; Mashima, T.; Takashima, T.; Okuyama, K. Augmentation of boiling heat transfer from horizontal cylinder to liquid by movable particles. Heat Transf. Res. 2002, 31, 28-41. [CrossRef]

101. Noh, H.; Kim, J.M.; Jo, H.J.; Park, H.S.; Hwang, D.K.; Kim, M.H. Effect of surface structure and coating on the heat transfer deflection behavior in the early stage of nucleate boiling. Int. J. Heat Mass Transf. 2018, 126, 1315-1322. [CrossRef]

102. White, S.B.; Shih, A.J.; Pipe, K.P. Effects of nanoparticle layering on nanofluid and base fluid pool boiling heat transfer from a horizontal surface under atmospheric pressure. J. Appl. Phys. 2010, 107. [CrossRef]

103. White, S.B.; Shih, A.J.; Pipe, K.P. Boiling surface enhancement by electrophoretic deposition of particles from a nanofluid. Int. J. Heat Mass Transf. 2011, 54, 4370-4375. [CrossRef]

104. Quan, X.; Wang, D.; Cheng, P. An experimental investigation on wettability effects of nanoparticles in pool boiling of a nanofluid. Int. J. Heat Mass Transf. 2017, 108, 32-40. [CrossRef]

105. Jaikumar, A.; Kandlikar, S.G. Enhanced pool boiling heat transfer mechanisms for selectively sintered open microchannels. Int. J. Heat Mass Transf. 2015, 88, 652-661. [CrossRef]

106. Gu, Y.; Xu, S.; Wu, X. Thermal conductivity enhancements and viscosity properties of water based Nanofluid containing carbon nanotubes decorated with ag nanoparticles. Heat Mass Transf. Stoffuebertragung 2018, 54, 1847-1852. [CrossRef] 
107. Jaikumar, A.; Kandlikar, S.G. Ultra-high pool boiling performance and effect of channel width with selectively coated open microchannels. Int. J. Heat Mass Transf. 2016, 95, 795-805. [CrossRef]

108. Kim, J.H.; Kim, J.M.; Jerng, D.W.; Kim, E.Y.; Ahn, H.S. Effect of aluminum oxide and reduced graphene oxide mixtures on critical heat flux enhancement. Int. J. Heat Mass Transf. 2018, 116, 858-870. [CrossRef]

109. Gupta, S.K.; Misra, R.D. An experimental investigation on pool boiling heat transfer enhancement using $\mathrm{Cu}-\mathrm{Al}_{2} \mathrm{O}_{3}$ nano-composite coating. Exp. Heat Transf. 2018, 1-26. [CrossRef]

110. Forrest, E.; Williamson, E.; Buongiorno, J.; Hu, L.-W.W.; Rubner, M.; Cohen, R. Augmentation of nucleate boiling heat transfer and critical heat flux using nanoparticle thin-film coatings. Int. J. Heat Mass Transf. 2010, 53, 58-67. [CrossRef]

111. Jung, J.-Y.; Kim, E.S.; Kang, Y.T. Stabilizer effect on CHF and boiling heat transfer coefficient of alumina/water nanofluids. Int. J. Heat Mass Transf. 2012, 55, 1941-1946. [CrossRef]

112. Ali, H.M.; Generous, M.M.; Ahmad, F.; Irfan, M. Experimental investigation of nucleate pool boiling heat transfer enhancement of $\mathrm{TiO}_{2}$-water based nanofluids. Appl. Therm. Eng. 2017, 113, 1146-1151. [CrossRef]

113. Chang, J.Y.; You, S.M. Enhanced boiling heat transfer from microporous surfaces: Effects of a coating composition and method. Int. J. Heat Mass Transf. 1997, 40, 4449-4460. [CrossRef]

114. Kim, J.H.; Rainey, K.N.; You, S.M.; Pak, J.Y. Mechanism of Nucleate Boiling Heat Transfer Enhancement from Microporous Surfaces in Saturated FC-72. J. Heat Transf. 2002, 124, 500. [CrossRef]

115. Chopkar, M.; Das, A.K.; Manna, I.; Das, P.K. Pool boiling heat transfer characteristics of ZrO2-water nanofluids from a flat surface in a pool. Heat Mass Transf. 2008, 44, 999-1004. [CrossRef]

116. Bang, I.C.; Heung Chang, S. Boiling heat transfer performance and phenomena of Al2O3-water nano-fluids from a plain surface in a pool. Int. J. Heat Mass Transf. 2005, 48, 2407-2419. [CrossRef]

117. Tehver, J.; Sui, H.; Temkina, V. Heat transfer and hysteresis phenomena in boiling on porous plasma-sprayed surface. Exp. Therm. Fluid Sci. 1992, 5, 714-727. [CrossRef]

118. Rajabzadeh Dareh, F.; Haghshenasfard, M.; Nasr Esfahany, M.; Salimi Jazi, H. Experimental investigation of time and repeated cycles in nucleate pool boiling of alumina/water nanofluid on polished and machined surfaces. Heat Mass Transf. Stoffuebertragung 2018, 54, 1653-1668. [CrossRef]

119. Jaikumar, A.; Rishi, A.; Gupta, A.; Kandlikar, S.G. Microscale Morphology Effects of Copper-Graphene Oxide Coatings on Pool Boiling Characteristics. J. Heat Transf. 2017, 139, 111509. [CrossRef]

120. Liu, B.; Cao, Z.; Zhang, Y.; Wu, Z.; Pham, A.D.; Wang, W.; Yan, Z.; Wei, J.; Sundén, B. Pool boiling heat transfer of N-pentane on micro/nanostructured surfaces. Int. J. Therm. Sci. 2018, 130, 386-394. [CrossRef]

121. Ray, M.; Bhaumik, S. Nucleate Pool Boiling Heat Transfer of Hydro-Fluorocarbon Refrigerant R134a on TiO2Nanoparticle Coated Copper Heating Surfaces. Heat Transf. Eng. 2018, 7632, 1-10. [CrossRef]

122. Das, S.; Saha, B.; Bhaumik, S. Experimental study of nucleate pool boiling heat transfer of water by surface functionalization with crystalline TiO2nanostructure. Appl. Therm. Eng. 2017, 113, 1345-1357. [CrossRef]

123. Song, G.; Davies, P.A.; Wen, J.; Xu, G.; Quan, Y. Nucleate pool boiling heat transfer of SES36 fluid on nanoporous surfaces obtained by electrophoretic deposition of $\mathrm{Al}_{2} \mathrm{O}_{3}$. Appl. Therm. Eng. 2018, 141, 143-152. [CrossRef]

124. Lee, J.S.; Lee, J.S. Conjugate heat transfer analysis for the effect of the eccentricity of hydrophobic dot arrays on pool boiling. Appl. Therm. Eng. 2017, 110, 844-854. [CrossRef]

125. Bostanci, H.; Joshua, N.E. Nucleate Boiling of Dielectric Liquids on Hydrophobic and Hydrophilic Surfaces. In Proceedings of the ASME 2015 International Mechanical Engineering Congress and Exposition, Volume 8A: Heat Transfer and Thermal Engineering, Houston, TX, USA, 13-19 November 2015; p. V08AT10A036.

126. Gong, S.; Cheng, P. Lattice Boltzmann simulations for surface wettability effects in saturated pool boiling heat transfer. Int. J. Heat Mass Transf. 2015, 85, 635-646. [CrossRef]

127. Mohammadi, N.; Fadda, D.; Choi, C.K.; Lee, J.; You, S.M. Effects of surface wettability on pool boiling of water using super-polished silicon surfaces. Int. J. Heat Mass Transf. 2018, 127, 1128-1137. [CrossRef]

128. Ji, W.T.; Zhao, P.F.; Zhao, C.Y.; Ding, J.; Tao, W.Q. Pool boiling heat transfer of water and nanofluid outside the surface with higher roughness and different wettability. Nanoscale Microscale Thermophys. Eng. 2018, 1-28. [CrossRef]

129. Kim, J.M.; Yu, D.I.; Park, H.S.; Moriyama, K.; Kim, M.H. Smart surface in pool boiling: Thermally-induced wetting transition. Int. J. Heat Mass Transf. 2017, 109, 231-241. [CrossRef] 
130. Chang, Y.W.; Arenales, M.R.; Kuo, L.S.; Chuang, Y.H.; Chen, P.H. Experimental Investigation on the Effect of Size and Pitch of Hydrophobic Square Patterns on the Pool Boiling Heat Transfer Performance of Cylindrical Copper Surface. Inventions 2018, 3, 15. [CrossRef]

131. Betz, A.R.; Jenkins, J.R.; Kim, C.-J.; Attinger, D. Significant boiling enhancement with surfaces combining superhydrophilic and superhydrophobic patterns. In Proceedings of the 2011 IEEE 24th International Conference on Micro Electro Mechanical Systems, Cancun, Mexico, 23-27 January 2011; pp. 1193-1196.

132. Betz, A.R.; Jenkins, J.; Kim, C.J.; Attinger, D. Boiling heat transfer on superhydrophilic, superhydrophobic, and superbiphilic surfaces. Int. J. Heat Mass Transf. 2013, 57, 733-741. [CrossRef]

133. Hsu, C.-C.; Chen, P.-H. Surface wettability effects on critical heat flux of boiling heat transfer using nanoparticle coatings. Int. J. Heat Mass Transf. 2012, 55, 3713-3719. [CrossRef]

134. Takata, Y.; Hidaka, S.; Uraguchi, T. Boiling Feature on a Super Water-Repellent Surface. Heat Transf. Eng. 2006, 27, 25-30. [CrossRef]

135. Takata, Y.; Hidaka, S.; Cao, J.M.; Nakamura, T.; Yamamoto, H.; Masuda, M.; Ito, T. Effect of surface wettability on boiling and evaporation. Energy 2005, 30, 209-220. [CrossRef]

136. Coyle, C.; O’Hanley, H.; Phillips, B.; Buongiorno, J.; McKrell, T. Effects of Hydrophobic Surface Patterning on Boiling Heat Transfer and Critical Heat Flux of Water at Atmospheric Pressure. In Proceedings of the ASME 2013 Power Conference, Volume 2: Reliability, Availability and Maintainability (RAM); Plant Systems, Structures, Components and Materials Issues; Simple and Combined Cycles; Advanced Energy Systems and Renewables (Wind, Solar and Geothermal); Energy Water Nexus; Thermal Hydraulics and CFD; Nuclear Plant Design, Licensing and Construction; Performance Testing and Performance Test Codes, Boston, MA, USA, 29 July-1 August 2013; p. V002T11A005.

137. Zupančič, M.; Steinbücher, M.; Gregorčič, P.; Golobič, I. Enhanced pool-boiling heat transfer on laser-made hydrophobic/superhydrophilic polydimethylsiloxane-silica patterned surfaces. Appl. Therm. Eng. 2015, 91, 288-297. [CrossRef]

138. Kumar, S.; Suresh, S.; Aneesh, C.R.; Kumar, S.; Praveen, A.S.; Raji, K. Flow boiling heat transfer enhancement on copper surface using Fe doped $\mathrm{Al}_{2} \mathrm{O}_{3}-\mathrm{TiO}_{2}$ composite coatings. Appl. Surf. Sci. 2015, 334, 102-109. [CrossRef]

139. Bourdon, B.; Di Marco, P.; Rioboo, R.; Marengo, M.; De Coninck, J. Enhancing the onset of pool boiling by wettability modification on nanometrically smooth surfaces. Int. Commun. Heat Mass Transf. 2013, 45, 11-15. [CrossRef]

140. Girard, A.R. Pool Boiling Heat Transfer of Water on Hydrophilic Surfaces with Different Wettability. In Proceedings of the ASME 2016 International Mechanical Engineering Congress and Exposition, Volume 8: Heat Transfer and Thermal Engineering, Phoenix, AZ, USA, 11-17 November 2016; pp. 1-12.

141. Zhang, B.J.; Ganguly, R.; Kim, K.J.; Lee, C.Y. Control of pool boiling heat transfer through photo-induced wettability change of titania nanotube arrayed surface. Int. Commun. Heat Mass Transf. 2017, 81, 124-130. [CrossRef]

142. Son, H.H.; Cho, Y.S.; Kim, S.J. Experimental study of saturated pool boiling heat transfer with FeCrAl-and Cr-layered vertical tubes under atmospheric pressure. Int. J. Heat Mass Transf. 2019, 128, 418-430. [CrossRef]

143. Deng, D.; Wan, W.; Shao, H.; Tang, Y.; Feng, J.; Zeng, J. Effects of operation parameters on flow boiling characteristics of heat sink cooling systems with reentrant porous microchannels. Energy Convers. Manag. 2015, 96, 340-351. [CrossRef]

144. El-genk, M.S.; Parker, J.L. Enhanced boiling of HFE-7100 dielectric liquid on porous graphite. Energy Convers. Manag. 2005, 46, 2455-2481. [CrossRef]

145. Bartle, R.S.; Menon, K.; Walsh, E. Pool boiling of resin-impregnated motor windings geometry. Appl. Therm. Eng. 2018, 130, 854-864. [CrossRef]

146. Chen, G.; Li, C.H. Combined effects of liquid wicking and hydrodynamic instability on pool boiling critical heat flux by two-tier copper structures of nanowires and microgrooves. Int. J. Heat Mass Transf. 2019, 129, 1222-1231. [CrossRef]

147. Mori, S.; Maruoka, N.; Okuyama, K. Critical heat flux enhancement by a two-layer structured honeycomb porous plate in a saturated pool boiling of water. Int. J. Heat Mass Transf. 2018, 118, 429-438. [CrossRef]

148. Liter, S.G.; Kaviany, M. Pool-boiling CHF enhancement by modulated porous-layer coating: Theory and experiment. Int. J. Heat Mass Transf. 2001, 44, 4287-4311. [CrossRef] 
149. Nguyen, T.B.; Liu, D.; Kayes, M.I.; Wang, B.; Rashin, N.; Leu, P.W.; Tran, T. Critical heat flux enhancement in pool boiling through increased rewetting on nanopillar array surfaces. Sci. Rep. 2018, 8, 1-9. [CrossRef] [PubMed]

150. Hwang, G.-S.; Kaviany, M. Critical heat flux in thin, uniform particle coatings. Int. J. Heat Mass Transf. 2006, 49, 844-849. [CrossRef]

151. Min, D.H.; Hwang, G.S.; Usta, Y.; Cora, O.N.; Koc, M.; Kaviany, M. 2-D and 3-D modulated porous coatings for enhanced pool boiling. Int. J. Heat Mass Transf. 2009, 52, 2607-2613. [CrossRef]

152. Nasersharifi, Y.; Kaviany, M.; Hwang, G. Pool-boiling enhancement using multilevel modulated wick. Appl. Therm. Eng. 2018, 137, 268-276. [CrossRef]

153. Yang, Y.; Ji, X.; Xu, J. Pool boiling heat transfer on copper foam covers with water as working fluid. Int. J. Therm. Sci. 2010, 49, 1227-1237. [CrossRef]

154. Coursey, J.S.; Roh, H.; Kim, J.; Boudreaux, P.J. Graphite Foam Thermosyphon Evaporator Performance: Parametric Investigation of the Effects of Working Fluid, Liquid Level, and Chamber Pressure. In Proceedings of the ASME 2002 International Mechanical Engineering Congress and Exposition, New Orleans, LA, USA, 17-22 November 2002.

155. Wong, K.K.; Leong, K.C. Saturated pool boiling enhancement using porous lattice structures produced by Selective Laser Melting. Int. J. Heat Mass Transf. 2018, 121, 46-63. [CrossRef]

156. Zhang, C.; Zhang, L.; Xu, H.; Li, P.; Qian, B. Performance of pool boiling with 3D grid structure manufactured by selective laser melting technique. Int. J. Heat Mass Transf. 2019, 128, 570-580. [CrossRef]

157. Deng, D.; Feng, J.; Huang, Q.; Tang, Y.; Lian, Y. Pool boiling heat transfer of porous structures with reentrant cavities. Int. J. Heat Mass Transf. 2016, 99, 556-568. [CrossRef]

158. Deng, D.; Wan, W.; Feng, J.; Huang, Q.; Qin, Y.; Xie, Y. Comparative experimental study on pool boiling performance of porous coating and solid structures with reentrant channels. Appl. Therm. Eng. 2016, 107, 420-430. [CrossRef]

159. Mori, S.; Yokomatsu, F.; Utaka, Y. Enhancement of critical heat flux using spherical porous bodies in saturated pool boiling of nanofluid. Appl. Therm. Eng. 2018, 144, 219-230. [CrossRef]

160. Zhou, J.; Liu, B.; Qi, B.; Wei, J.; Mao, H. Experimental investigations of bubble behaviors and heat transfer performance on micro/nanostructure surfaces. Int. J. Therm. Sci. 2019, 135, 133-147. [CrossRef]

161. Cao, Z.; Liu, B.; Preger, C.; Wu, Z.; Zhang, Y.; Wang, X.; Messing, M.E.; Deppert, K.; Wei, J.; Sundén, B. Pool boiling heat transfer of FC-72 on pin-fin silicon surfaces with nanoparticle deposition. Int. J. Heat Mass Transf. 2018, 126, 1019-1033. [CrossRef]

162. Qu, Z.G.; Xu, Z.G.; Zhao, C.Y.; Tao, W.Q. Experimental study of pool boiling heat transfer on horizontal metallic foam surface with crossing and single-directional V-shaped groove in saturated water. Int. J. Multiph. Flow 2012, 41, 44-55. [CrossRef]

163. Li, C.H.; Li, T.; Hodgins, P.; Hunter, C.N.; Voevodin, A.A.; Jones, J.G.; Peterson, G.P. Comparison study of liquid replenishing impacts on critical heat flux and heat transfer coefficient of nucleate pool boiling on multiscale modulated porous structures. Int. J. Heat Mass Transf. 2011, 54, 3146-3155. [CrossRef]

164. Hendricks, T.J.; Krishnan, S.; Choi, C.; Chang, C.H.; Paul, B. Enhancement of pool-boiling heat transfer using nanostructured surfaces on aluminum and copper. Int. J. Heat Mass Transf. 2010, 53, 3357-3365. [CrossRef]

165. Jun, S.; Wi, H.; Gurung, A.; Amaya, M.; You, S.M. Pool Boiling Heat Transfer Enhancement of Water Using Brazed Copper Microporous Coatings. J. Heat Transf. 2016, 138, 071502. [CrossRef]

166. Ha, M.; Graham, S. Pool boiling enhancement through hierarchical texturing of surfaces. In Proceedings of the 2016 15th IEEE Intersociety Conference on Thermal and Thermomechanical Phenomena in Electronic Systems (ITherm), Las Vegas, NV, USA, 31 May-3 June 2016; pp. 388-394.

167. Arik, M.; Bar-Cohen, A.; You, S.M. Enhancement of pool boiling critical heat flux in dielectric liquids by microporous coatings. Int. J. Heat Mass Transf. 2007, 50, 997-1009. [CrossRef]

168. Kumar, S.; Suresh, S.; Yang, Q.; Aneesh, C.R. An experimental investigation on flow boiling heat transfer enhancement using spray pyrolysed alumina porous coatings. Appl. Therm. Eng. 2014, 71, 508-518. [CrossRef]

169. Patil, C.M.; Kandlikar, S.G. Pool boiling enhancement through microporous coatings selectively electrodeposited on fin tops of open microchannels. Int. J. Heat Mass Transf. 2014, 79, 816-828. [CrossRef]

170. El-Genk, M.S.; Parker, J.L. Nucleate boiling of FC-72 and HFE-7100 on porous graphite at different orientations and liquid subcooling. Energy Convers. Manag. 2008, 49, 733-750. [CrossRef] 
171. Voglar, J.; Gregorčič, P.; Zupančič, M.; Golobič, I. Boiling performance on surfaces with capillary-length-spaced one- and two-dimensional laser-textured patterns. Int. J. Heat Mass Transf. 2018, 127, 1188-1196. [CrossRef]

172. Wang, Y.Q.; Luo, J.L.; Heng, Y.; Mo, D.C.; Lyu, S.S. Wettability modification to further enhance the pool boiling performance of the micro nano bi-porous copper surface structure. Int. J. Heat Mass Transf. 2018, 119, 333-342. [CrossRef]

173. Kim, J.M.; Kong, B.T.; Lee, H.B.R.; Wongwises, S.; Ahn, H.S. Effect of h-BN coating on nucleate boiling heat transfer performance in pool boiling. Exp. Therm. Fluid Sci. 2018, 98, 12-19. [CrossRef]

174. Dewangan, A.K.; Kumar, A.; Kumar, R. Experimental Study of Nucleate Pool Boiling of R-134a and R-410a on a Porous Surface. Heat Transf. Eng. 2018, 7632, 1-10. [CrossRef]

175. Li, T.; Lee, J.-H.; Wang, R.; Kang, Y.T. Enhancement of heat transfer for thermal energy storage application using stearic acid nanocomposite with multi-walled carbon nanotubes. Energy 2013, 55, 752-761. [CrossRef]

176. Berber, S.; Kwon, Y.-K.; Tománek, D. Unusually High Thermal Conductivity of Carbon Nanotubes. Phys. Rev. Lett. 2000, 84, 4613-4616. [CrossRef] [PubMed]

177. Ghosh, S.; Calizo, I.; Teweldebrhan, D.; Pokatilov, E.P.; Nika, D.L.; Balandin, A.A.; Bao, W.; Miao, F.; Lau, C.N. Extremely high thermal conductivity of graphene: Prospects for thermal management applications in nanoelectronic circuits. Appl. Phys. Lett. 2008, 92, 151911. [CrossRef]

178. Yamagiwa, K. Liquid-phase synthesis of vertically aligned carbon nanotubes and related nanomaterials on preheated alloy substrates. Jpn. J. Appl. Phys. 2018, 57. [CrossRef]

179. Sezer, N.; Koc, M. Dispersion Stability of CNT and CNT/Metal-based Nanofluids. In Proceedings of the International Conference on Thermal Engineering: Theory and Applications, Doha, Qatar, 25-28 February 2018; pp. 1-4.

180. Sezer, N.; Koç, M. Oxidative acid treatment of carbon nanotubes. Surf. Interfaces 2018. [CrossRef]

181. Khan, S.A.; Ali, A.; Hussien, M.A.; Koc, M. Study of CNF Coating for Pool-Boiling and Condensation. In Proceedings of the International Conference on Sustainable Energy and Environmental Protection, Changsha, China, 23-25 June 2017; pp. 27-30.

182. Dharmendra, M.; Suresh, S.; Sujith Kumar, C.S.; Yang, Q. Pool boiling heat transfer enhancement using vertically aligned carbon nanotube coatings on a copper substrate. Appl. Therm. Eng. 2016, 99, 61-71. [CrossRef]

183. Seo, H.; Yun, H.D.; Kwon, S.-Y.; Bang, I.C. Hybrid Graphene and Single-Walled Carbon Nanotube Films for Enhanced Phase-Change Heat Transfer. Nano Lett. 2016, 16, 932-938. [CrossRef] [PubMed]

184. Murshed, S.M.S.; Nieto de Castro, C.A. Superior thermal features of carbon nanotubes-based nanofluids-A review. Renew. Sustain. Energy Rev. 2014, 37, 155-167. [CrossRef]

185. Khanikar, V.; Mudawar, I.; Fisher, T. Effects of carbon nanotube coating on flow boiling in a micro-channel. Int. J. Heat Mass Transf. 2009, 52, 3805-3817. [CrossRef]

186. Kousalya, A.S.; Singh, K.P.; Fisher, T.S. Heterogeneous wetting surfaces with graphitic petal-decorated carbon nanotubes for enhanced flow boiling. Int. J. Heat Mass Transf. 2015, 87, 380-389. [CrossRef]

187. Seo, G.H.; Hwang, H.; Yoon, J.; Yeo, T.; Son, H.H.; Jeong, U.; Jeun, G.; Choi, W.; Kim, S.J. Enhanced critical heat flux with single-walled carbon nanotubes bonded on metal surfaces. Exp. Therm. Fluid Sci. 2015, 60, 138-147. [CrossRef]

188. Bertossi, R.; Caney, N.; Gruss, J.A.; Dijon, J.; Fournier, A.; Marty, P. Influence of carbon nanotubes on deionized water pool boiling performances. Exp. Therm. Fluid Sci. 2015, 61, 187-193. [CrossRef]

189. Launay, S.; Fedorov, A.; Joshi, Y.; Cao, A.; Ajayan, P.M. Hybrid micro-nano structured thermal interfaces for pool boiling heat transfer enhancement. Microelectron. J. 2006, 37, 1158-1164. [CrossRef]

190. Park, S.-S.; Kim, Y.H.; Jeon, Y.H.; Hyun, M.T.; Kim, N.-J. Effects of spray-deposited oxidized multi-wall carbon nanotubes and graphene on pool-boiling critical heat flux enhancement. J. Ind. Eng. Chem. 2015, 24, 276-283. [CrossRef]

191. Ahn, H.S.; Sathyamurthi, V.; Banerjee, D. Pool Boiling Experiments on a Nano-Structured Surface. IEEE Trans. Compon. Packag. Technol. 2009, 32, 156-165. [CrossRef]

192. Ahn, H.S.; Sinha, N.; Zhang, M.; Banerjee, D.; Fang, S.; Baughman, R.H. Pool Boiling Experiments on Multiwalled Carbon Nanotube (MWCNT) Forests. J. Heat Transf. 2006, 128, 1335. [CrossRef]

193. Ujereh, S.; Fisher, T.; Mudawar, I. Effects of carbon nanotube arrays on nucleate pool boiling. Int. J. Heat Mass Transf. 2007, 50, 4023-4038. [CrossRef] 
194. Kim, J.M.; Park, S.C.; Kong, B.T.; Lee, H.B.R.; Ahn, H.S. Effect of porous graphene networks and micropillar arrays on boiling heat transfer performance. Exp. Therm. Fluid Sci. 2018, 93, 153-164. [CrossRef]

195. Jaikumar, A.; Kandlikar, S.G.; Gupta, A. Pool Boiling Enhancement through Graphene and Graphene Oxide Coatings. Heat Transf. Eng. 2017, 38, 1274-1284. [CrossRef]

196. Rishi, A.M.; Gupta, A.; Kandlikar, S.G. Improving liquid supply pathways on graphene oxide coated surface for enhanced pool boiling heat transfer performance. In Proceedings of the ASME 2018 16th International Conference on Nanochannels, Microchannels, and Minichannels, Dubrovnik, Croatia, 10-13 June 2018; pp. 1-9.

197. Udaya Kumar, G.; Soni, K.; Suresh, S.; Ghosh, K.; Thansekhar, M.R.; Dinesh Babu, P. Modified surfaces using seamless graphene/carbon nanotubes based nanostructures for enhancing pool boiling heat transfer. Exp. Therm. Fluid Sci. 2018, 96, 493-506. [CrossRef]

198. Sadaghiani, A.K.; Motezakker, A.R.; Kasap, S.; Kaya, I.I.; Koşar, A. Foamlike 3D Graphene Coatings for Cooling Systems Involving Phase Change. ACS Omega 2018, 3, 2804-2811. [CrossRef]

199. Pialago, E.J.T.; Kwon, O.K.; Jin, J.S.; Park, C.W. Nucleate pool boiling of R134a on cold sprayed Cu-CNT-SiC and Cu-CNT-AlN composite coatings. Appl. Therm. Eng. 2016, 103, 684-694. [CrossRef]

200. Ujereh, S.O.; Mudawar, I.; Amama, P.B.; Fisher, T.S.; Qu, W. Enhanced Pool Boiling Using Carbon Nanotube Arrays on a Silicon Surface. In Proceedings of the ASME 2005 International Mechanical Engineering Congress and Exposition, Heat Transfer, Part A, Orlando, FL, USA, 5-11 November 2005; Volume 2005, pp. 691-696.

201. McHale, J.P.; Garimella, S.V.; Fisher, T.S.; Powell, G.A. Pool Boiling Performance Comparison of Smooth and Sintered Copper Surfaces with and Without Carbon Nanotubes. Nanoscale Microscale Thermophys. Eng. 2011, 15, 133-150. [CrossRef]

202. Jaikumar, A.; Santhanam, K.S.V.; Kandlikar, S.G.; Raya, I.B.P.; Raghupathi, P. Electrochemical Deposition of Copper on Graphene with High Heat Transfer Coefficient. ECS Trans. 2015, 66, 55-64. [CrossRef]

203. Seo, H.; Chu, J.H.; Kwon, S.-Y.; Bang, I.C. Pool boiling CHF of reduced graphene oxide, graphene, and SiC-coated surfaces under highly wettable FC-72. Int. J. Heat Mass Transf. 2015, 82, 490-502. [CrossRef]

204. Seo, H.; Seo, S.B.; Moon, S.B.; Kwon, S.Y.; Kim, J.H.; Bang, I.C. Investigation of Boiling Heat Transfer and Critical Heat Flux Enhancement for SiC and Graphene Layers on ITO Surfaces. In Proceedings of the ASME 2013 4th International Conference on Micro/Nanoscale Heat and Mass Transfer, Hong Kong, China, 11-14 December 2013.

205. Kamatchi, R.; Kumaresan, G. Investigations on pool boiling critical heat flux, transient characteristics and bonding strength of heater wire with aqua based reduced graphene oxide nanofluids. Chin. J. Chem. Eng. 2018, 26, 445-454. [CrossRef]

(C) 2018 by the authors. Licensee MDPI, Basel, Switzerland. This article is an open access article distributed under the terms and conditions of the Creative Commons Attribution (CC BY) license (http://creativecommons.org/licenses/by/4.0/). 